\title{
Swiss halocarbon emissions for 2019 to 2020 assessed from re- gional atmospheric observations
}

Dominique Rust ${ }^{1,2}$, Ioannis Katharopoulos ${ }^{1,3}$, Martin K. Vollmer ${ }^{1}$, Stephan Henne ${ }^{1}$, Simon O'Doherty $^{4}$, Daniel Say ${ }^{4}$, Lukas Emmenegger ${ }^{1}$, Renato Zenobi ${ }^{2}$, Stefan Reimann ${ }^{1}$

$5 \quad{ }^{1}$ Laboratory for Air Pollution/Environmental Technology, Empa, Swiss Federal Laboratories for Materials Science and Technologies, Dübendorf, Switzerland

${ }^{2}$ Department of Chemistry and Applied Biosciences, ETH, Swiss Federal Institute of Technology, Zurich, Switzerland

${ }^{3}$ Institute for Atmospheric and Climate Science, ETH, Swiss Federal Institute of Technology, Zurich, Switzerland

${ }^{4}$ Atmospheric Chemistry Research Group, University of Bristol, Bristol, UK

Correspondence to: Stefan Reimann (stefan.reimann@empa.ch)

Abstract. Halocarbons are emitted by various anthropogenic activities to the atmosphere, where they contribute to global warming and stratospheric ozone-depletion. To determine national halocarbon emissions, the so-called "top-down" approach relies on atmospheric observations, at sites that reflect emissions on a country level, and combines these observations with inverse modelling methods. In this study, we present 12 months (September 2019 to September 2020) of continuous atmospheric observations of 28 halocarbons from a measurement campaign at the Beromünster tall tower in Switzerland. The site is sensitive to the most densely populated area of Switzerland, the Swiss Plateau, thus the measurements were well suited to derive Swiss halocarbon emissions. Emissions were calculated by two different top-down methods, a tracer-ratio method (TRM) with carbon monoxide (CO) as the independent tracer, and a Bayesian inversion (BI), based on atmospheric transport simulations using FLEXPART-COSMO. The results were compared to previously reported top-down emission estimates, based on measurements at the high-Alpine site Jungfraujoch, and to the "bottom-up" Swiss national greenhouse gas (GHG) inventory, as annually reported to the United Nations Framework Convention on Climate Change (UNFCCC). We observed ongoing outgassing from existing foams and refrigerators for the ozone-depleting, banned chlorofluorocarbons (CFCs) and the regulated hydrochlorofluorocarbons (HCFCs), confirming their large historical use. For the major hydrofluorocarbons (HFCs) HFC-125 $\left(\mathrm{CHF}_{2} \mathrm{CF}_{3}\right)$ and HFC-32 $\left(\mathrm{CH}_{2} \mathrm{~F}_{2}\right)$, our calculated emissions of $99 \pm 29 \mathrm{Mg} \mathrm{yr}^{-1}$ and $46 \pm 13 \mathrm{Mg} \mathrm{yr}^{-1}$ were in good agreement with the national Swiss inventory values, whereas for HFC-134a $\left(\mathrm{CH}_{2} \mathrm{FCF}_{3}\right)$ our result of $300 \pm 85 \mathrm{Mg} \mathrm{yr}^{-1}$ was about $30 \%$ lower than the UNFCCC reported value. For the other investigated $\mathrm{HFCs}$, perfluorocarbons ( $\mathrm{PFCs}$ ), $\mathrm{SF}_{6}$ and $\mathrm{NF}_{3}$, emissions were small and in agreement with the inventory. Finally, we report the first country-based emission estimates of a total of $50 \mathrm{Mg}$ $\mathrm{yr}^{-1}$ for three recently phased-in, unregulated hydrofluoroolefins (HFOs), HFO-1234yf $\left(\mathrm{CF}_{3} \mathrm{CF}=\mathrm{CH}_{2}\right)$, HFO$1234 \mathrm{ze}(\mathrm{E})\left((\mathrm{E})-\mathrm{CF}_{3} \mathrm{CH}=\mathrm{CHF}\right)$ and $\mathrm{HCFO}-1233 \mathrm{zd}(\mathrm{E})\left((\mathrm{E})-\mathrm{CF}_{3} \mathrm{CH}=\mathrm{CHCl}\right)$.

\section{Introduction}

Anthropogenic halocarbons are emitted to the atmosphere through a wide range of industrial and consumptionbased activities. They are commonly used as cooling agents in refrigeration and air conditioning, as foam blowing agents, in fire extinguishers or as solvents (WMO, 2018). Halocarbons with long atmospheric lifetimes have considerable global warming potentials (GWPs). In addition, chlorine or bromine-containing halocarbons, e.g. chlorofluorocarbons (CFCs), hydrochlorofluorocarbons (HCFCs), and brominated alkanes (halons), act as strong ozone- 
depleting substances. The production and consumption of these substances is regulated under the Montreal Proto-

col (MP) on Substances that Deplete the Ozone Layer (UNEP, 2020). Hydrofluorocarbons (HFCs), which are not ozone depleting but strong greenhouse gases (GHGs), are part of the Kigali Amendment to the MP and of the Kyoto Protocol (KP) under the framework of the United Nations Framework Convention on Climate Change (UNFCCC). Whereas the Kigali Amendment foresees a binding down-scaling of global production and consumption of HFCs, the KP only prescribes annual reporting as emission inventories and reduction of emissions, in a basket together with other GHGs. The submitted national emission inventories are so-called "bottom-up" derived accountings of the individual halocarbon emissions, based on production, sales and consumption statistics, and emission factors (Weiss et al., 2011; Bergamaschi et al., 2018). Because of the growing pressure to reduce HFC emissions, a new generation of unsaturated HFCs has been marketed for about a decade - the hydrofluoroolefins (HFOs). These substances have short lifetimes and low GWPs and, therefore, are not regulated. In EU member states, however, they are subject to reporting under the F-gas regulation (EU, 2014).

Among the most important CFCs and halons, $\mathrm{CFC}-11\left(\mathrm{CCl}_{3} \mathrm{~F}\right)$ and $\mathrm{CFC}-12\left(\mathrm{CCl}_{2} \mathrm{~F}_{2}\right)$ were extensively used globally as foam blowing and cooling agents, respectively, while the minor $\mathrm{CFC}-13\left(\mathrm{CClF}_{3}\right)$ and $\mathrm{CFC}-115\left(\mathrm{CClF}_{2} \mathrm{CF}_{3}\right)$ were only applied for special refrigeration purposes (Vollmer et al., 2018). H-1211 ( $\left.\mathrm{CBrClF}_{2}\right)$ and $\mathrm{H}-2402$ $\left(\mathrm{CBrF}_{2} \mathrm{CBrF}_{2}\right)$ were used as fire extinguishing agents. Regarding the $\mathrm{HCFCs}$, $\mathrm{HCFC}-22\left(\mathrm{CHF}_{2} \mathrm{Cl}\right)$ was mostly used as a cooling agent in domestic and commercial refrigeration. HCFC-141b $\left(\mathrm{CH}_{3} \mathrm{CCl}_{2} \mathrm{~F}\right)$ and $\mathrm{HCFC}-142 \mathrm{~b}$ $\left(\mathrm{CH}_{3} \mathrm{CClF}_{2}\right)$ were used as foam blowing agents, and HCFC-141b was additionally applied as a solvent in different cleaning applications. HCFC-124 was, besides others, used as cooling agent in special applications. Whereas the CFCs and halons were phased-out in developed countries from 1995 onwards, the HCFCs are now also banned for use in new equipment in Europe, with an allowance of $0.5 \%$ of the 1989 base level consumption until 2030 for maintenance of existing refrigeration and air conditioning systems. However, CFCs, halons, and HCFCs remain in many long-lived products, from which they are still continuously emitted (WMO, 2018; Montzka et al., 2021). Among the HFCs, HFC-134a $\left(\mathrm{CH}_{2} \mathrm{FCF}_{3}\right)$ is applied as a cooling agent in (auto)mobile air conditioners, where it has gradually replaced CFC-12 since the early 1990s. In addition, it is used as aerosol propellant in metered-dose inhalers and as foam blowing agent (Simmonds et al., 2017; WMO, 2018; Li et al., 2019). HFC-125 ( $\left.\mathrm{CHF}_{2} \mathrm{CF}_{3}\right)$ is widely applied in refrigerant blends for stationary air conditioners, and HFC-32 $\left(\mathrm{CH}_{2} \mathrm{~F}_{2}\right)$, mainly together with HFC-125, is a component of refrigerant blends that were introduced as substitute for HCFC-22 in stationary air conditioning (Graziosi et al., 2017). HFC-134a, HFC-125, and HFC-32 are among the most widely used refrigerants in Europe. HFC-152a $\left(\mathrm{CH}_{3} \mathrm{CHF}_{2}\right)$ is mainly used as a foam blowing agent, but also as an aerosol propellant and in refrigeration blends, replacing CFCs and HCFCs (Simmonds et al., 2016). Compared to the other HFCs, HFC-152a has the lowest lifetime of 1.6 years (Supplement 1). HFC-245fa $\left(\mathrm{CHF}_{2} \mathrm{CH}_{2} \mathrm{CF}_{3}\right)$ and $\mathrm{HFC}-365 \mathrm{mfc}$ $\left(\mathrm{CH}_{3} \mathrm{CF}_{2} \mathrm{CH}_{2} \mathrm{CF}_{3}\right)$ are mainly used as foam blowing agents, substituting the phased-out HCFC-141b and CFC-11 (Vollmer et al., 2006; Stemmler et al., 2007; Vollmer et al., 2011). HFC-227ea $\left(\mathrm{CF}_{3} \mathrm{CHFCF}_{3}\right)$ and HFC-236fa $\left(\mathrm{CF}_{3} \mathrm{CH}_{2} \mathrm{CF}_{3}\right)$ are mainly used as fire extinguishing agents as replacement for the halons (Laube et al., 2010; Vollmer et al., 2011), with smaller usage as propellants or special cooling agents. HFC-4310mee is used as a cleaning agent for various applications, replacing $\mathrm{CFC}-113\left(\mathrm{CCl}_{2} \mathrm{FCClF}_{2}\right), \mathrm{HCFC}-141 \mathrm{~b}$, and methyl chloroform (Le Bris et al., 2018), and as a solvent for specific uses, replacing PFCs (Arnold et al., 2014). Of the PFCs, PFC$116\left(\mathrm{C}_{2} \mathrm{~F}_{6}\right)$ and PFC-318 $\left(\mathrm{c}-\mathrm{C}_{4} \mathrm{~F}_{8}\right)$ are emitted from the semiconductor industry, while the former is also emitted from aluminum production. The production of aluminum is also the main anthropogenic source of PFC-14 $\left(\mathrm{CF}_{4}\right)$. $\mathrm{NF}_{3}$ is emitted from the electronics industry, and $\mathrm{SF}_{6}$ is applied in electrical insulation and additionally emitted 

$\left.\mathrm{CF}_{3} \mathrm{CH}=\mathrm{CHF}\right)$, and $\mathrm{HCFO}-1233 \mathrm{zd}(\mathrm{E})\left((\mathrm{E})-\mathrm{CF}_{3} \mathrm{CH}=\mathrm{CHCl}\right)$ were first detected in the atmosphere by Vollmer et al. (2015), using measurements from Dübendorf (Switzerland). While HFO-1234yf is currently applied as refrigerant in mobile air conditioners to replace HFC-134a, and in refrigerant blends (together with HFC-134a, HFC-125, and HFC-32), HFO-1234ze(E) is mainly used in refrigerant blends for residential and commercial air conditioners (together with HFC-32, HFC-152a, and isobutane), and as foam blowing agent and propellant. Although HCFO$1233 z d(E)$ contains a chlorine atom, its contribution to stratospheric ozone depletion is minimal due to its short atmospheric lifetime (Supplement 1).

To monitor the long-term, large-scale trends of halocarbons in the atmosphere, the global measurement network Advanced Global Atmospheric Gases Experiment (AGAGE), consisting of 15 remote background sites, and a measurement program operated by the National Oceanic and Atmospheric Administration (NOAA), have been established (Prinn et al., 2000, 2018; NOAA, 2021). Based on these atmospheric observations, the effectiveness of the regulative measures are monitored by means of the changing trends of the global atmospheric concentrations of the halocarbons.

To assess bottom-up derived halocarbon emissions on the global or the hemispheric scale with atmospheric observations, box and inverse modelling methods were developed (WMO, 2010; Bergamaschi et al., 2018; Prinn et al., 2018). This "top-down" quantification complements the existing bottom-up national and global emission inventories and adds to the credibility of reported emission inventories, or can be used to cover incomplete reporting. To derive a more robust confirmation of emissions, efforts to narrow down the top-down modelling methods to subcontinental, regional or country scale have been made (e.g. Weiss et al., 2011; Brunner et al., 2017; Bergamaschi et al., 2018). However, an important limitation in the development of top-down methods for subregional scale is the sparsity of regional observations. To improve national emission estimates, high-frequency in situ measurements are needed at higher spatial resolution, which regularly capture pollution events from the region of interest. To determine European continental emissions, measurements from the AGAGE stations Mace Head (Ireland), Tacolneston (England), Jungfraujoch (Switzerland), Monte Cimone (Italy), and Ny-Ålesund (Spitsbergen) have previously been used for top-down modelling (e.g. Lunt et al., 2015; Brunner et al., 2017; Graziosi et al., 2017; Manning et al., 2021). In addition, temporary, regional measurement campaigns have been conducted to further constrain emissions from Eastern Europe (Keller et al., 2012) and the Eastern Mediterranean (Schoenenberger et al., 2018). Furthermore, continuous in situ measurements of halogenated trace gases started at the Taunus Observatory in central Germany in 2018 (Lefrancois et al., 2021) with the aim of improving observational sensitivity of large parts of Germany, the Benelux region and France (Schuck et al., 2018). In the United Kingdom (UK) and Ireland, the Deriving Emissions linked to Climate Change (DECC) network, of which Mace Head and Tacolneston are also part, was launched in 2012. The continuous measurements of GHGs at these sites are used for top-down estimations of UK emissions (e.g. Manning et al., 2021). However, the number of (European) countries for which emissions are specifically quantified based on regional observations, is still very limited, and in Europe, UNFCCC reported inventories are complemented with top-down estimates only for the UK and Switzerland (Bergamaschi et al., 2018).

In Switzerland, until now, top-down halocarbon emission estimates were calculated based on continuous measurements at the high-altitude research station at Jungfraujoch (Reimann et al., 2021). However, Jungfraujoch is located at a topographically complex location that is only periodically influenced by direct air transports from the polluted Swiss boundary layer. Hence, emission estimates for Switzerland are based on only a few transport events reaching 
Jungfraujoch, mostly during the summer months (Reimann et al., 2004). In addition to halocarbons, Swiss emissions of methane $\left(\mathrm{CH}_{4}\right)$ and nitrous oxide $\left(\mathrm{N}_{2} \mathrm{O}\right)$ have been estimated annually by Bayesian inverse modelling since 2013 and 2017, respectively (Henne et al. 2016). These estimates include observations from the tall tower site Beromünster and are reported as part of the Swiss National Inventory Report (NIR) to UNFCCC.

In this study, we present continuous halocarbon measurements at the tall tower of Beromünster, in a rural area in central Switzerland (Berhanu et al., 2016). From September 2019 to September 2020, hourly measurements of 59 halocarbons, which are constantly monitored within the AGAGE network, were performed. Air samples were analysed with a Medusa pre-concentration unit coupled to gas chromatography (GC) and mass spectrometry (MS; Miller et al., 2008; Arnold et al., 2012). We present the atmospheric records of four CFCs, two halons, four HCFCs, 10 HFCs, three perfluorocarbons (PFCs), $\mathrm{SF}_{6}, \mathrm{NF}_{3}$, and three HFOs. Based on the measurements, Swiss emissions for these 28 halocarbons were calculated by two different top-down approaches: a tracer-ratio method (TRM), with carbon monoxide (CO) as the tracer, and a Bayesian inversion (BI). Where possible, the emissions were compared to the Swiss bottom-up inventory, reported to the UNFCCC and to the top-down estimates from Jungfraujoch (Reimann et al., 2021). Simulated maps generated from the BI modelling indicated the spatial distribution of Swiss emissions for selected halocarbons of different generations and applications.

\section{Materials and methods}

\subsection{Measurement site}

The measurements of atmospheric halocarbons were performed at the Blosenberg tall tower, close to Beromünster, Switzerland, at a sample inlet height of $212 \mathrm{~m}$ above ground level (a.g.1.). The tower is located in a rural area in the middle of the Swiss Plateau at $47.2^{\circ} \mathrm{N}, 8.2^{\circ} \mathrm{E}$, at an altitude of $797 \mathrm{~m}$ a.s.l. The site was originally equipped with GHG and meteorological measurements at five different heights up to $212 \mathrm{~m}$ a.g.l. as part of the CarboCount$\mathrm{CH}$ project (Oney et al., 2015; Berhanu et al., 2016). Later, it was integrated into the Swiss National Air Pollution Monitoring Network (NABEL), the European Monitoring and Evaluation Program (EMEP), and the Global Atmosphere Watch (GAW) regional station network of the World Meteorological Organisation (WMO). The area referred to as the Swiss Plateau is a landscape north $(\mathrm{N})$ of the Swiss Alps, south (S) of the Jura Mountains and confined by Lake Geneva in the southwest (SW) and Lake Constance in the northeast (NE). Covering one third of the Swiss surface area, the Swiss Plateau represents the most densely populated (more than two-thirds of the Swiss population) and industrially most active region of Switzerland. Medium and large size industrial enterprises are located in this area. Cities with the highest population on the Swiss Plateau are Zürich (population: 415 000), about

$15040 \mathrm{~km} \mathrm{NE}$, Lucerne (population: 82 000) about $20 \mathrm{~km}$ south-southeast (SSE), and Bern (population: 144 000), about $70 \mathrm{~km} \mathrm{SW}$.

Wind observations collected at $212 \mathrm{~m}$ a.g.l. during the measurement campaign are summarized in Fig. 1. During the campaign, the major wind direction at Beromünster was from west-southwest (WSW), followed by wind from the direction of NE, with maximum wind velocities of $24 \mathrm{~m} \mathrm{~s}^{-1}$ at the top of the tower (212 $\mathrm{m}$ ). This bimodal wind direction distribution is typical for the Swiss Plateau with the near surface flow being channeled by the mountain ridges to the south (Alps) and north (Jura). 


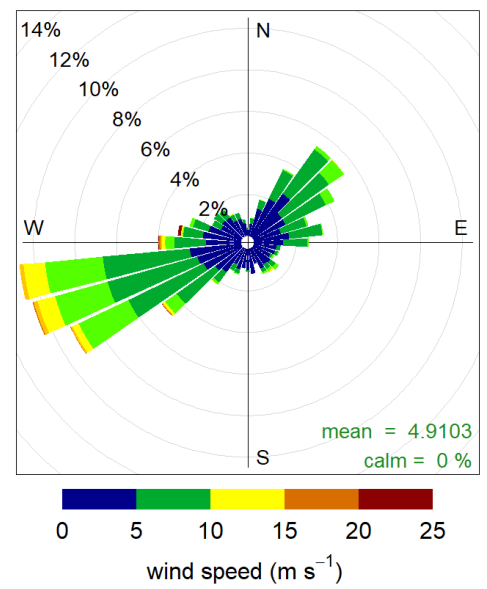

Frequency of counts by wind direction (\%)

Figure 1: Wind rose for the Beromünster station for the duration of the measurement campaign and based on $10 \mathrm{~min}$ average wind observations. The frequencies of wind from different directions are given as percentage, wind speeds are given in colored intervals in $\mathrm{m} \mathrm{s}^{-1}$.

Beromünster was determined to be sensitive to the major part of the Swiss Plateau (Fig. 2 and Oney et al., 2015) and is thus well suited to capture halocarbon emissions from the latter on a small to medium regional scale.

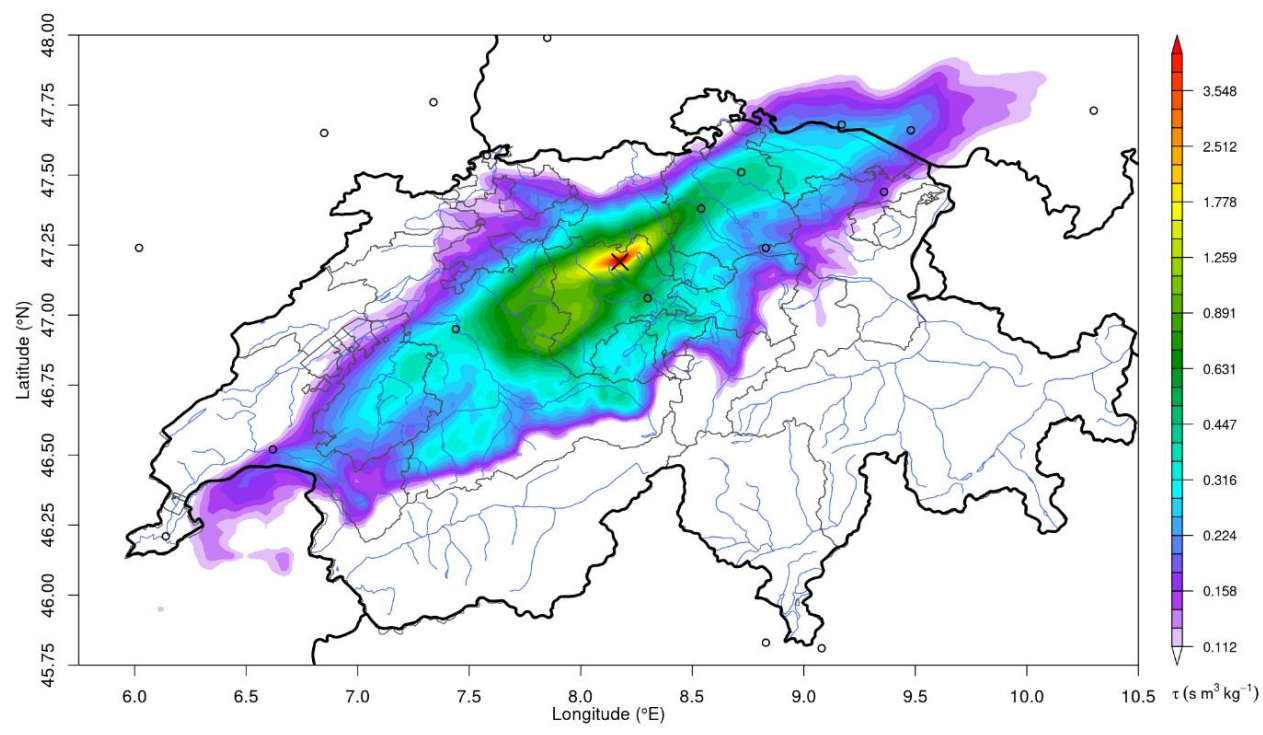

Figure 2: Modelled total surface sensitivity for Beromünster (black cross) for the duration of the measurement campaign as obtained from the FLEXPART simulation (Sect. 2.4). The surface sensitivity is given as particle residence time per air density and surface area.

Additional halocarbon measurements used for the inverse modelling in this study (Sect. 2.4 and Sect. 2.5) came from the AGAGE measurement stations at Jungfraujoch $\left(46.5^{\circ} \mathrm{N}, 8.0^{\circ} \mathrm{E}, 3580 \mathrm{~m}\right.$ a.s.1., inlet height $-15 \mathrm{~m}$ a.g.1., i.e. inlet height is below instrument height), Mace Head (53.3 $\mathrm{N},-9.9^{\circ} \mathrm{E}, 8 \mathrm{~m}$ a.s.l., inlet height $10 \mathrm{~m}$ a.g.1.), and Tacolneston (52.5 $\mathrm{N}, 1.1^{\circ} \mathrm{E}, 56 \mathrm{~m}$ a.s.l. inlet height $185 \mathrm{~m}$ a.g.l.) (Prinn et al., 2018). 


\subsection{Sampling and analysis}

In situ halocarbon measurements were conducted with a Medusa pre-concentration unit, coupled to GC and MS (Miller et al., 2008; Arnold et al., 2012; Prinn et al., 2018). Ambient air was sampled at $212 \mathrm{~m}$ a.g.l. through a continuously flushed tube, consisting of an innermost ethylene copolymer coating on a slit overlapping aluminum layer and an outer high-density polyethylene jacket (SERTOflex, $12 \mathrm{~mm}$ OD, $8 \mathrm{~mm}$ ID). From this sample stream, $2 \mathrm{~L}$ of air were diverted to the Medusa every $70 \mathrm{~min}$ at a flow rate of $100 \mathrm{~mL} / \mathrm{min}$. To prevent condensed water from entering the sampling module, the main air stream was drawn through a custom-built in-line water trap consisting of a stainless-steel dip tube, which was regularly checked for liquid water. The integrity of the sampling line was confirmed by comparing the in situ measurements with those of simultaneously drawn flask samples from a second sampling line at the same inlet height. Additionally, all joints which connected the sampling line to the measurement devices, were sprayed with high-concentration gaseous tracers and found leak-free.

In the AGAGE measurement setup, the air sample is pre-concentrated at low temperatures in a two-trap system (Medusa). Our Medusa used a Stirling cooler (Ametek Sunpower, CryoTel-GT), leading to sample trapping temperatures of $-165^{\circ} \mathrm{C}$ for the first, and $-180{ }^{\circ} \mathrm{C}$ for the second trap. After pre-concentration, the analytes were flushed into a GC (Agilent 6890N), using helium as the carrier gas (He 6.0, Messer Switzerland), and detected by quadrupole electron ionization MS (Agilent 5975) in selected ion monde (SIM). Chromatographic separation was achieved with a CP-PoraBOND Q column (0.32 mm i.d. x $25 \mathrm{~m}, 5 \mu \mathrm{m}$ film thickness, Agilent). GCWerks was used as instrument control and data processing software.

To correct for short-term instrumental drift, the measurements of two consecutive ambient air samples were bracketed by measurements of a working standard. The working standard consisted of ambient air compressed into a 34 L internally electro-polished and humidified stainless steel tank (Essex Industries Inc., USA), using an oil-free air compressor (SA-6, RIX Industries, USA). Real-air working standards are collected at Rigi-Seebodenalp, Switzerland $\left(47.1^{\circ} \mathrm{N}, 8.5^{\circ} \mathrm{E}, 1030 \mathrm{~m}\right.$ a.s.1) during relatively clean-air conditions. To better track the MS sensitivities for low-abundant substances like HFO-1234yf, HFO-1234ze(E), and HCFO-1233zd(E), we spiked these substances into the standards. For HFO-1234yf, HFO-1234ze(E), and HCFO-1233zd(E) the respective final working standard concentrations were on average 1.5, 5.0, and 0.6 ppt. The working standards used at Beromünster were crosscalibrated within the AGAGE relative calibration scale by a predefined inter-calibration routine, which consists of a hierarchy of calibration standards provided by the Scripps Institution of Oceanography (SIO) (Miller et al., 2008). In addition, some substances were calibrated on primary scales produced by the Swiss Federal Laboratories for Materials Science and Technologies (Empa), the Federal Institute of Metrology in Switzerland (METAS) or the University of Bristol (UB).

Three types of uncertainties were considered: the accuracy of the primary calibration scale originating from the production of the primary standard, the uncertainty from the propagation of the calibration standards within the AGAGE calibration hierarchy (Prinn et al., 2018), and the measurement precisions. The uncertainties are listed in Supplement 2. If the accuracy of the primary calibration scale was unknown for a substance, it was set to $2 \%$. If the uncertainty of the standard propagation was unknown, the measurement precision was propagated instead. Measurement precisions were derived from the difference of the pair of working standard measurements that were bracketing the actual air measurements. They were below $3 \%$ for 26 of the 28 reported substances and below $5 \%$ for HFC-4310mee and HFC-236fa. 
The analytical setup was operated in a temperature-controlled $\left( \pm 2{ }^{\circ} \mathrm{C}\right)$ trailer adjacent to the tower. R410a (a mixture of HFC-32 $\left(\mathrm{CH}_{2} \mathrm{~F}_{2}\right)$ and HFC-125 $\left(\mathrm{CHF}_{2} \mathrm{CF}_{3}\right), 50 \%$ by weight each) was used as refrigerant for the air conditioner. Weekly trailer indoor air measurements suggested the absence of any major refrigerant leaks.

For the use as tracer in the tracer-ratio method, $\mathrm{CO}$ was measured as part of the Swiss GHG monitoring network CarboCount-CH with a Picarro G2410 analyzer (Picarro Inc., USA) using cavity ring-down spectroscopy (CRDS).

The analytical setup and instrument calibration was described in detail by Berhanu et al. (2016).

\subsection{Emission estimation by the tracer-ratio method (TRM)}

The TRM relates emissions of a target analyte to those of a tracer with known emissions during pollution events. The underlying assumption of the TRM is that both the target analyte and the tracer have similar spatial and temporal emission sources and are transported to the receptor, i.e. the measurement site, without any significant additional production or loss (Yao et al., 2012). This also implies that the analyte and the tracer behave similarly in the atmosphere or that the transport distance to the measurement site is either short enough for the analyte and tracer ratio to be preserved or long enough so that analyte and tracer emissions from multiple sources are well-mixed. If the distance to the receptor is long enough, emissions from different sources influence the signal, and the degree of analyte and tracer correlation of individual events becomes dispersed. In this case, the TRM is applicable to emission estimation for a larger emitting region and over an increased time period. Overall we consider Beromünster as an adequate site for the TRM because the Swiss pollution sources are at a significant distance and thus well mixed, and because the observed substances are very stable in the atmosphere and thus not modified during their transport.

In this study, CO was used as the reference tracer. It was assumed that in Switzerland CO is only emitted anthropogenically during the combustion of biofuels and fossil fuels in road transport and non-industrial combustion processes, leading to relatively constant CO emissions for all seasons (Guevara et al., 2021). Other sources of CO, i.e. emissions from wildfires or oxidation of methane and non-methane volatile organic carbons (VOCs), were assumed negligible or constant for the Swiss domain (Oney et al., 2017). The main sink of CO is oxidation with hydroxyl radicals, resulting in an atmospheric lifetime of $22 \mathrm{~d}$ in summer in the northern hemisphere (Miller et al., 2012), which is much longer than the transport time of CO from Swiss emission sources to Beromünster. Hence, it was possible to neglect $\mathrm{CO}$ degradation in the current approach.

The emissions $\left(E_{x}\right)$ of a target analyte in units of $\mathrm{Mg} \mathrm{yr}^{-1}$ were calculated by applying Eq. (1):

$E_{\mathrm{X}}=E_{\mathrm{CO}} \frac{\Delta X}{\Delta C O} \frac{M_{\mathrm{X}}}{M_{\mathrm{CO}}} 10^{-3}$.

$\Delta X$ (in units of $\mathrm{ppt}=\mathrm{pmol} / \mathrm{mol}$ ) and $\Delta C O$ (in units of $\mathrm{ppb}=\mathrm{nmol} / \mathrm{mol}$ ) are the respective enhancements of atmos-

240 pheric concentrations above background of the target analyte and CO, respectively. To determine enhancement above background, the $\mathrm{CO}$ data were first averaged within the sampling time interval of each halocarbon measurement. Pollution events were then distinguished from background concentrations by applying the statistical "robust extraction of baseline signal" (REBS) method (Ruckstuhl et al., 2012). Since this method yields the atmospheric background level as a "baseline", the two expressions are used synonymously in the following. To determine a method uncertainty, different baseline variations were calculated and incorporated into the emission estimation. REBS settings included the use of a tuning factor $(b=3.5)$ and three different settings of the temporal window width, i.e. a bandwidth parameter of 15, 30, and 60 days. Next to a smooth baseline, the REBS method provides a global estimate of the uncertainty of the baseline. To add to the determination of the method uncertainty, different subsets of data above baseline were created by scaling the REBS uncertainty to different levels by multiplying 
with specific sigma factors, i.e. $1,1.5$, and 2 . The fractions of measured baseline concentrations relative to the total number of data points and the average background concentrations for the considered halocarbons for a specific example of REBS settings are given in Supplement 4.1. Multiplication with the ratio of molecular weights $\left(M_{x}\right.$ and $M_{C O}$; both in units of $\mathrm{g} \mathrm{mol}^{-1}$ ) is needed to convert from mass to volume mixing ratios. $E_{C O}$ is the a priori emission inventory value of $\mathrm{CO}$. To cover the timeframe of the measurement campaign, the $\mathrm{CO}$ inventory values for the years 2019 and 2020 were weighed accordingly, to result in a CO emission value of $152.9 \mathrm{Gg} \mathrm{yr}^{-1}$. Correspondent to Reimann et al. (2020), the yet unreported Swiss CO inventory value for 2020 was calculated from the latest available CO inventory values reported to CLRTAP/EMEP and the average trend over the preceding three years.

For the emission calculation, the data were filtered based on simulated near-surface residence time of the sampled air masses (Sect. 2.4). Near-surface residence times were evaluated by country/region. Residence times over Switzerland were divided by the total residence time over land areas in the model domain. Two different minimal ratios of Swiss residence time were used for observation filtering, i.e. for events with $50 \%$ and $75 \%$ relative country residence times, respectively. A map, depicting the distribution of the relative country residence times of the air masses measured at Beromünster for different regions, is given in Supplement 4.2. The air measured at Beromünster resided most of the time over Switzerland, France and Germany.

To calculate the halocarbon-CO emission ratio all remaining pollution events were summed up to give a term for $\triangle X$ and $\triangle C O$, respectively, and the two terms were then divided. The values arising from the different baseline and country residence time settings were averaged to give a final emission value.

Several sources of error were taken into account throughout the tracer-ratio calculations. For the halocarbon and $\mathrm{CO}$ measurements, the corresponding measurement precisions at 1-sigma (68\%) confidence level, and the uncertainty of the modelled baseline fit were propagated by standard Gaussian error propagation. The two types of calibration uncertainties were added to the halocarbon measurements before calculation of the halocarbon-CO emission ratio. Final uncertainties for emission estimations were calculated at the 2-sigma (95\%) confidence level. As described before, method uncertainties arising from the choice of parameters for baseline fitting and relative country residence time were incorporated by taking into account the different settings for the baseline fitting parameters and the two different levels of relative country residence times.

For some substances, i.e. CFC-13, CFC-115, H-2402, HCFC-22, HCFC-124, HFC-23, HFC-236fa, PFC-318, PFC-14, and $\mathrm{NF}_{3}$, only a very limited number of pollution events with significant magnitude were observed. Thus, depending on the set REBS and country residence time parameters, the number of data points included in the emission estimation with the TRM was greatly reduced (Supplement 4.3), therefore reducing the reliability of the emission results for these substances.

\subsection{Atmospheric transport simulations}

Receptor-oriented backward simulations with the Lagrangian Particle Dispersion Model (LPDM) FLEXPART (Stohl et al., 2005; Pisso et al., 2019) were carried out to estimate the sensitivity of the observed atmospheric concentrations to regional emissions (source sensitivities, Seibert et al., 2004). Depending on the location of the sites, different versions of the model, driven by different meteorological input fields, were utilized. For the Swiss sites in complex terrain (Jungfraujoch and Beromünster), the FLEXPART version adjusted for input from the regional numerical weather prediction (NWP) model COSMO was run with meteorological analysis fields opera- 
tionally provided hourly by the Swiss national weather service (MeteoSwiss) at a horizontal resolution of approximately $7 \mathrm{~km}$ by $7 \mathrm{~km}$ (COSMO-7). For the two additional sites located on the British Isles (Mace Head and Tacolneston), which is towards the northwestern domain boundary of the COSMO-7 domain, the main version of FLEXPART (version 9.2_Empa) for use with input from the European Centre for Medium-range Weather Forecasts (ECMWF) Integrated Forecasting System (IFS) was applied. The employed input fields had a horizontal resolution of $0.2^{\circ}$ by $0.2^{\circ}$ in the Alpine area and $1^{\circ}$ by $1^{\circ}$ elsewhere. For both model versions, a similar backward simulation strategy was followed, releasing 50000 model particles during 3-hourly intervals at each measurement location and tracing these particles backward in time for 4 and 10 days for FLEXPART-COSMO and FLEXPART-IFS, respectively.

The resulting source sensitivities, $m_{i j}$, connect the spatial distribution of the emissions $\left(E_{i, j}\right)$ with the mole fraction of a tracer in the receptor $(\chi)$ via a linear relationship

where $\chi_{b}$ is the average mole fraction of the particles at the end points of the backward simulation and is comparable to boundary conditions in Eulerian model simulations. Here, $\chi_{b}$ was not explicitly simulated or taken from a larger scale model, but is replaced by an observation-based baseline mole fraction (Sect. 2.5).

Next to total receptor mole fractions, spatially resolved FLEXPART source sensitivities were also used to identify situations in which air masses sampled at Beromünster were dominated by surface contact over the Swiss domain. For this purpose, the sum of $m_{i, j}$ for different land regions was calculated for each model interval and the fraction of Swiss residence time to total residence time over land was determined.

\subsection{Emission estimation by Bayesian inverse (BI) modelling}

The second top-down approach for estimating Swiss emissions utilizes the FLEXPART simulated source sensitivities coupled with a Bayesian inversion (BI) framework. The latter is used to obtain an optimized state of the emissions combining a priori knowledge of the emissions, model simulated source sensitivities, and observations at the receptor sites. The method applied in this study was extensively described by Henne et al. (2016) for methane and frequently applied to halocarbon emissions (e.g., Park 2021, Simmonds 2020, Rigby 2019, Schönenberger 2018). Here, we only summarize the most important aspects and point out necessary modifications.

315 The inversions in this study cover the period of the field campaign in Beromünster. Daily mean values of the observations at Beromünster, Jungfraujoch, Tacolneston, and Mace Head were utilized. Modelled source sensitivities for the four receptor sites were used together with an a priori estimate for the emissions $x_{b}$ and the observations $y$ in a BI framework, in order to obtain an optimized state for the emissions. The inversion domain extends from $12.0^{\circ} \mathrm{W}$ to $21.1^{\circ} \mathrm{E}$ and $36.0^{\circ} \mathrm{S}$ to $57.5^{\circ} \mathrm{N}$. The a posteriori emissions were calculated by minimizing the following cost function

$J=\frac{1}{2}\left(x-x_{\mathrm{b}}\right)^{\mathrm{T}} \mathrm{B}^{-1}\left(x-x_{\mathrm{b}}\right)+\frac{1}{2}\left(\mathrm{M} x-\chi_{o}\right)^{\mathrm{T}} \mathrm{R}^{-1}\left(\mathrm{M} x-\chi_{o}\right)$,

where $x$ denotes the a posteriori state vector comprised of gridded emissions and baseline mole fractions, $x_{b}$ indicates the a priori state, $M$ corresponds to the source sensitivities, $\chi_{o}$ to the observations, and $B$ and $R$ to the uncertainty covariance matrices of the a priori emissions state and the combined model-observation uncertainty. Both $B$ and $R$ are symmetric block matrices. Matrix $B$ contains two blocks, $B^{E}$ and $B^{B}$, describing the uncertainty covariance of the gridded emissions and the baseline, respectively. Matrix $R$ contains as many blocks as the number of the receptor sites (in our case four), and each block element contains both model and observations uncertainty 
covariances. The set up of each block and how the elements of these matrices were filled was described in detail by Henne et al. (2016). Finally, a maximum likelihood (ML) optimization algorithm was used besides the base inversion to further optimize the set of uncertainty covariance parameters used in the covariance matrices (Henne et al., 2016).

The minimization of the cost function Eq. (3) reduces the difference between observed and simulated values $\left(\chi^{0}, M x\right)$, additionally constrained by the difference between the a priori and a posteriori emission estimates. A posteriori emissions are given by

For this study, the a priori baseline of each halocarbon was determined by the REBS method (Sect. 2.3) and was optimized according to the corresponding site. REBS settings included the use of the tuning factor $\mathrm{b}=3.5$, a temporal window width of 30 days, and a maximum of 10 iterations. For Beromünster, the baselines calculated for Jungfraujoch were applied, because synoptic scale baselines are needed to follow particles to their endpoints of the simulation outside the inversion domain. The a priori emissions used for the HFCs, PFCs, $\mathrm{SF}_{6}$, and $\mathrm{NF}_{3}$ were taken from the 2018 national reports to the UNFCCC (UNFCCC, 2021) for the reporting countries in the model domain. For CFCs, halons, HCFCs, and HFOs, the 2019 Swiss emissions estimated based on the Jungfraujoch data (Reimann et al., 2021), and as annually submitted to the Swiss Office for the Environment (FOEN), were used. The a priori emissions of these substances for the remaining countries in the domain were calculated according to the Swiss emissions on a per-capita basis. A priori uncertainties were obtained through the above-mentioned ML approach. Because the Jungfraujoch-based estimates rely on the TRM that is based on a very limited number of data points (Reimann et al., 2021), sensitivity inversions were implemented to assess the variability of the emissions if the confidence interval of the Jungfraujoch-based a priori emission values was large. For the sensitivity testing, half and double of the a priori estimates for all countries of the inversion domain were used. The sensitivity simulations showed only little response to the used a priori value, therefore only the results with the mean a priori simulations were considered. The HFOs were treated as inert for the inversions, assuming that the transport times from emission sources to BRM are sufficiently small to avoid larger chemical losses.

For all the halocarbons in this study, population-based priors were utilized. Flat priors were tested for the subset of HFC-23, $\mathrm{SF}_{6}$, and PFC-14. However, the simulation results were inferior in terms of performance and thus the population-based distribution was pursued. The inversion output provided gridded emissions for the major part of the European domain. To calculate the Swiss emissions, the emissions from the grids lying inside the Swiss borders were extracted. The inversions performance and reliability of results for the different substances was assessed through several statistical measures. In Supplement 5 the most important statistical measures and the inversions reliability are summarized. The chi index assesses the probability density distribution of the posterior model residuals and a posteriori emission differences. Ideally, a value close to one can be achieved with well-chosen covariance matrices. The degree of freedom (DF) describes the reduction in the normalized error of the prior due to the number of available observations, and thus, is a measure of improvement of the posterior when compared to the prior. Two additional comparison statistics for the a posteriori simulated versus observed regional (above baseline) mole fractions at Beromünster were considered: the correlation coefficient, $r$, and the normalized standard deviation, nSD, which is the standard deviation of the simulations divided by the standard deviation of the observations. For both statistics, values close to one indicate favorable model performance. Based on these parameters, the reliability of the inversion calculations for the different substances was evaluated. For most substances, inversion 
results were deemed to be reliable. Exceptions were CFC-13, CFC-115, H-2402, HCFC-124, HFC-23, HFC-236fa,

PFC-318, and PFC-14, for which reported results should not be over-interpreted.

Table 1: For each halocarbon, the following information is listed: the measurement sites included in the Bayesian inverse (BI) modelling, i.e. Beromünster (BRM), Jungfraujoch (JFJ), Tacolneston (TAC) or Mace Head (MHD), the source of the a priori value, and the UNFCCC (UNFCCC, 2021) or Jungfraujoch-based (Reimann et al., 2021) a priori value for Switzerland, rounded to two significant figures.

\begin{tabular}{|c|c|c|c|}
\hline substance & sites included in inversion & a priori information & $\begin{array}{l}\text { a priori value for Switzerland } \\
\left(\mathrm{Mg} \mathrm{yr}^{-1}\right)\end{array}$ \\
\hline CFC-11 & BRM, JFJ, TAC, MHD & CLIMGAS & 55 \\
\hline CFC-12 & BRM, JFJ, TAC, MHD & CLIMGAS & 50 \\
\hline CFC-13 & BRM, JFJ, TAC, MHD & CLIMGAS & 0.40 \\
\hline CFC-115 & BRM, JFJ, TAC, MHD & CLIMGAS & 1.0 \\
\hline $\mathrm{H}-1211$ & BRM, JFJ, TAC, MHD & CLIMGAS & 2.0 \\
\hline $\mathrm{H}-2402$ & BRM, JFJ, TAC, MHD & CLIMGAS & 0.20 \\
\hline HCFC-22 & BRM, JFJ, TAC, MHD & CLIMGAS & 4.0 \\
\hline HCFC-141b & BRM, JFJ, TAC & CLIMGAS & 7.0 \\
\hline HCFC-142b & BRM, TAC, MHD & CLIMGAS & 25 \\
\hline HCFC-124 & BRM, JFJ, TAC, MHD & CLIMGAS & 2.0 \\
\hline HFC-134a & BRM, JFJ, TAC, MHD & UNFCCC & 500 \\
\hline HFC-125 & BRM, JFJ, TAC, MHD & UNFCCC & 130 \\
\hline HFC-32 & BRM, JFJ, TAC, MHD & UNFCCC & 51 \\
\hline HFC-152a & BRM, JFJ, TAC, MHD & UNFCCC & 0.63 \\
\hline HFC-245fa & BRM, JFJ, TAC, MHD & UNFCCC & 2.6 \\
\hline HFC-365mfc & BRM, JFJ, TAC, MHD & UNFCCC & 4.6 \\
\hline HFC-23 & BRM, JFJ, TAC, MHD & UNFCCC & 0.59 \\
\hline HFC-227ea & BRM, JFJ, TAC, MHD & UNFCCC & 3.8 \\
\hline HFC-236fa & BRM, JFJ, TAC, MHD & UNFCCC & 0.51 \\
\hline HFC-4310mee & BRM, JFJ, TAC, MHD & UNFCCC & 0.45 \\
\hline PFC-116 & BRM, JFJ, TAC, MHD & UNFCCC & 3.0 \\
\hline PFC-318 & BRM, JFJ, MHD & UNFCCC & 2.0 \\
\hline PFC-14 & BRM, JFJ, TAC, MHD & UNFCCC & 0.70 \\
\hline $\mathrm{SF}_{6}$ & BRM, JFJ, TAC, MHD & UNFCCC & 7.0 \\
\hline $\mathrm{NF}_{3}$ & BRM, JFJ, MHD & UNFCCC & 0.050 \\
\hline HFO-1234yf & BRM, JFJ, TAC, MHD & CLIMGAS & 50 \\
\hline HFO-1234ze(E) & BRM, JFJ, TAC, MHD & CLIMGAS & 16 \\
\hline HCFO-1233zd(E) & BRM, JFJ, TAC, MHD & CLIMGAS & 40 \\
\hline
\end{tabular}

\section{Results and discussion}

\subsection{Measured time series}

The one-year Beromünster records are shown in Fig. 3 and Supplement 3 for the halocarbons with the highest atmospheric abundance and/or for which emissions were calculated. This includes four CFCs, two halons, four HCFCs, $10 \mathrm{HFCs}$, three PFCs, $\mathrm{SF}_{6}, \mathrm{NF}_{3}$, three HFOs, and $\mathrm{CO}$. Concentrations are reported as dry air mole fractions in $\mathrm{pmol} \mathrm{mol}^{-1}$ (ppt) for the halocarbons, and in $\mathrm{nmol} \mathrm{mol}^{-1}$ (ppb) for $\mathrm{CO}$. 

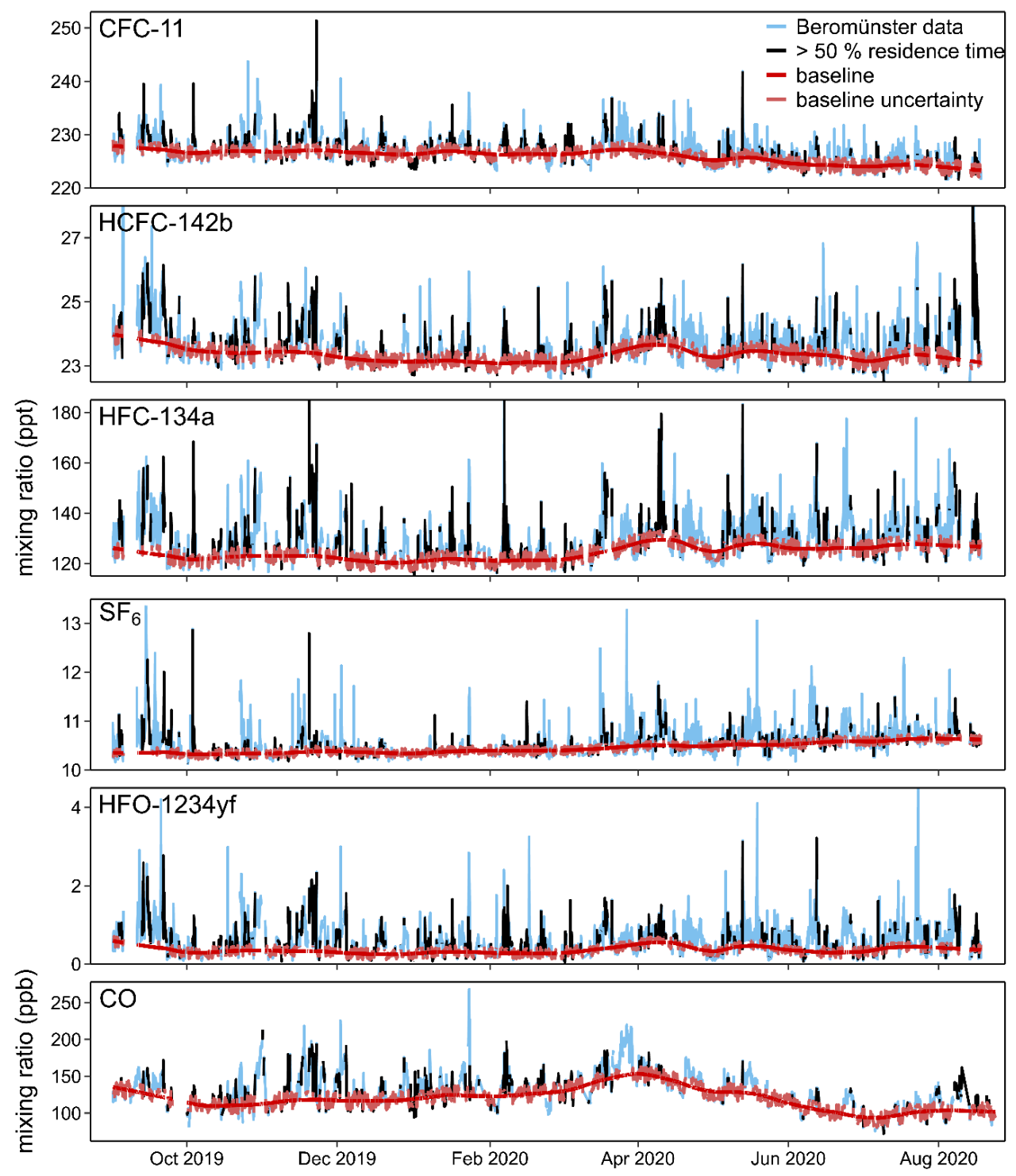

Figure 3: One-year time series of the atmospheric concentrations measured at Beromünster. Air samples with more than $50 \%$ relative residence time in Switzerland are highlighted in black. The baselines (red lines) calculated with a REBS bandwidth parameter of 30 days are shown with their uncertainty bands (light red) derived with the REBS sigma factor set to 1.5 .

The majority of the records show pollution events during the whole measurement campaign. For some substances, i.e. HCFC-142b, HFC-134a, HFC-125, HFC-32, HFC-152a, HFO-1234yf, HFO-1234ze(E), and HCFO$1233 z d(E)$, the pollution events quickly succeed each other within hourly or daily time intervals. Therefore, for these substances, a background concentration level is scarcely reached during the whole year, or only seasonally during the winter months. This can be explained by the extensive use of these halocarbons in various applications and their continuous emissions from regional sources captured by the site. In the following, the individual substances are discussed in more detail. 
For CFC-11, CFC-12, and H-1211, we were able to define solid baselines with some overlying structure arising from ongoing emissions of existing installations (banks), underlining their extensive historical use. For CFC-13, CFC-115, and $\mathrm{H}-2402$, pollution events were virtually absent, indicating minor historic use. In addition, HCFC-22, HCFC-141b, and the minor HCFC-124 $\left(\mathrm{CHClFCF}_{3}\right)$ showed few distinctive pollution events, whereas for HCFC-142b pollution events were more frequent with enhancements above baseline reaching a maximum larger than 6 ppt. Our observations underline the finding that these HCFCs are still emitted from outgassing of existing foams and refrigeration units.

For the HFCs, our measurements show the highest abundances and most frequent pollution events for HFC-134a, HFC-125, and HFC-32, with average background concentrations of around 120, 40, and $30 \mathrm{ppt}$, respectively. HFC-134a reached the highest pollution events of more than 80 ppt over baseline, whereas pollution events of HFC-125 and HFC-32 were smaller with maximum values of approximately 20 and 30 ppt. For HFC-152a we observed an average baseline concentration of about $10 \mathrm{ppt}$ with only minor enhancements. This can be explained by small emissions in Switzerland arising only from outgassing of existing foams, as there is no production of foams and the use as propellant is forbidden. HFC-245fa, HFC-365mfc, HFC-227ea, HFC-236fa, and HFC4310mee all showed clear baselines with a few distinctive pollution events, which, however, only lasted for a few hours. For these five HFCs, the majority of the emissions were localized outside of Switzerland - only $19 \%$ of the pollution events had a Swiss residence time above $50 \%$, and $5 \%$ above $75 \%$ residence time (REBS bandwidth of 30 days and sigma factor of 1.5). For HFC-227ea, we observed a few distinctive pollution events with a Swiss residence time larger than $50 \%$. Although the specified events were exceeding the baseline by about 1 ppt only, they may point at non-continuous, recurrent emissions of HFC-227ea. As one of the more abundant HFCs in the atmosphere, HFC-23 $\left(\mathrm{CHF}_{3}\right)$ showed an average baseline level of approximately 34 ppt. However, there was no notable number of significantly enhanced pollution events. This can be ascribed to the absence of HCFC-22 synthesis in Switzerland, from which HFC-23, besides minor emissions from specific other applications (Oram et al., 1998; Miller et al., 2010; Montzka et al., 2010; Stanley et al., 2020), is mainly emitted as unwanted by-product (WMO, 2018).

For $\mathrm{SF}_{6}$, sporadic pollution episodes were observed, with the major fraction of the highest events, however, showing a low contribution from Switzerland. For $\mathrm{NF}_{3}$ and PFC-14, the time series show little variability beyond measurement precision. $\mathrm{PFC}-14$ is emitted during the production of aluminum, while $\mathrm{NF}_{3}$ is produced during manufacturing processes in the electronic industry, both absent from within the footprint of the station. The other investigated PFCs are used in the semiconductor industry: PFC-116 shows sporadic pollution events, especially during the summer months and PFC-318 only shows two discernible events in March and July 2020. For both substances only about $20 \%$ of the pollution events are attributed to Switzerland with more than $50 \%$ country residence time.

For the newly produced HFO-1234yf, HFO-1234ze(E), and HCFO-1233zd(E), the average baseline levels were as low as $0.4,0.5$, and $0.2 \mathrm{ppt}$, respectively. More than $50 \%$ of the measurements were assigned to pollution events. The highest pollution events were seen for HFO-1234ze(E), exceeding 40 ppt over baseline, followed by lower events of about 4 ppt for HFO-1234yf and 2 ppt for HCFO-1233zd(E). Our observations confirm the increasing use of HFO-1234ze(E) and HFO-1234yf as refrigerants in Switzerland, and the fact that HCFO-1233zd(E) is only allowed for limited application as cooling agent and as foam blowing agent.

The time series of CO (used as the tracer in the TRM) shows a pronounced variability of the baseline with a maximum at the end of March and a minimum in July. Many high pollution events occur during the winter months, 
followed by fewer observed events during spring and summer, however not implying smaller emissions in summer but rather reflecting the faster mixing of surface emissions throughout a larger fraction of the troposphere (Sect. hemisphere. The seasonal variation of CO at Beromünster was already studied in detail by Satar et al. (2016), who found smaller seasonal amplitudes compared to other European tall tower stations.

\subsection{Emissions from Switzerland}

Based on the atmospheric measurements at Beromünster, Jungfraujoch, Mace Head, and Tacolneston, Swiss emissions were determined with the TRM (Sect. 2.3) and BI models (Sect. 2.5). The results are listed in Table 2 and are compared to the Swiss top-down emission estimates based on the Jungfraujoch data (Reimann et al., 2021), and, for HFCs, PFCs, $\mathrm{SF}_{6}$, and $\mathrm{NF}_{3}$, to the latest (2019) bottom-up inventory reported to the UNFCCC (UNFCCC, 2021). Because the Jungfraujoch-based Swiss emissions are calculated as three-year averages, the 2019 value is used for comparison instead of the 2020 value. The time series of the Swiss emission values since 2015 are presented in Fig. 4. For the Jungfraujoch and the inventory emissions, error bars are only depicted for the 2019 values. For the inventory values, uncertainties were assessed based on the information and uncertainties (at 1-sigma $(68 \%)$ confidence level) given in the NIR (FOEN, 2021 a) for the individual emission source categories, and on the detailed emission numbers submitted to the UNFCCC.

Figure 5 summarizes the 2019/2020 emission values, grouped for different halocarbon classes, and shows the corresponding values converted to $\mathrm{CO}_{2}$ equivalents. 
Table 2: Calculated Swiss emissions for 2019/2020, based on the Beromünster (BRM) measurements, with the tracerratio method (TRM) and Bayesian inverse (BI) modelling. The results are compared to the average of the Jungfraujoch (JFJ)-based emission values for 2019 and the Swiss inventory for 2019. The average BRM-TRM and BRM-BI values are rounded to two significant figures. Uncertainties are given at 2-sigma.

\begin{tabular}{|c|c|c|c|c|c|}
\hline substance & $\begin{array}{l}\text { average BRM-TRM/ } \\
\text { BRM-BI }\left(\mathrm{Mg} \mathrm{yr}^{-1}\right) \\
\text { 2019/2020 }\end{array}$ & $\begin{array}{l}\text { BRM-TRM } \\
\left(\mathrm{Mg} \mathrm{yr}^{-1}\right) \\
2019 / 2020\end{array}$ & $\begin{array}{l}\mathrm{BRM}-\mathrm{BI} \\
\left(\mathrm{Mg} \mathrm{yr}^{-1}\right) \\
2019 / 2020\end{array}$ & $\begin{array}{l}\text { JFJ-TRM } \\
\left(\mathrm{Mg} \mathrm{yr}^{-1}\right) \\
2019^{\mathrm{b})}\end{array}$ & $\begin{array}{l}\text { inventory } \\
\left(\mathrm{Mg} \mathrm{yr}^{-1}\right) \\
2019^{\mathrm{c})}\end{array}$ \\
\hline CFC-11 & $60 \pm 20^{\text {a) }}$ & $92 \pm 18$ & $28 \pm 8$ & $50 \pm 21$ & - \\
\hline CFC-12 & $27 \pm 10^{\mathrm{a})}$ & $46 \pm 9$ & $9 \pm 5$ & $21 \pm 25$ & - \\
\hline CFC-13 & $1.3 \pm 0.44^{\mathrm{a})}$ & $2 \pm 0.4$ & $0.6 \pm 0.1$ & $-1 \pm 2$ & - \\
\hline CFC-115 & $1.7 \pm 0.67^{\text {a) }}$ & $3 \pm 0.6$ & $0.4 \pm 0.3$ & $1 \pm 2$ & - \\
\hline H-1211 & $5.7 \pm 2.4$ & $8 \pm 2$ & $3.3 \pm 1.3$ & $2 \pm 1$ & - \\
\hline H-2402 & $0.34 \pm 0.10^{\mathrm{a})}$ & $0.5 \pm 0.1$ & $0.2 \pm 0.03$ & $0.2 \pm 0.6$ & - \\
\hline HCFC-22 & $23 \pm 9.3$ & $39 \pm 8$ & $8 \pm 5$ & $37 \pm 20$ & - \\
\hline HCFC-141b & $7.2 \pm 2.8$ & $11 \pm 2$ & $3 \pm 2$ & $6 \pm 4$ & - \\
\hline HCFC-142b & $14 \pm 4.6$ & $19 \pm 4$ & $10 \pm 2$ & $25 \pm 14$ & - \\
\hline HCFC-124 & $2.1 \pm 1.0^{\mathrm{a})}$ & $4 \pm 1$ & $0.2 \pm 0.2$ & $0.2 \pm 1$ & - \\
\hline HFC-134a & $300 \pm 85$ & $292 \pm 58$ & $311 \pm 62$ & $314 \pm 48$ & $448 \pm 135$ \\
\hline HFC-125 & $99 \pm 29$ & $94 \pm 19$ & $105 \pm 22$ & $77 \pm 11$ & $124 \pm 37$ \\
\hline HFC-32 & $46 \pm 13$ & $47 \pm 9$ & $45 \pm 9$ & $29 \pm 8$ & $54 \pm 16$ \\
\hline HFC-152a & $14 \pm 5.0^{\mathrm{a})}$ & $26 \pm 5$ & $2 \pm 0.7$ & $18 \pm 7$ & $0.4 \pm 0.8$ \\
\hline HFC-245fa & $2.3 \pm 0.81^{\text {a) }}$ & $4 \pm 0.8$ & $0.5 \pm 0.3$ & $8 \pm 3$ & $0.2 \pm 0.1$ \\
\hline HFC-365mfc & $7.0 \pm 2.9$ & $8 \pm 2$ & $6 \pm 2$ & $9 \pm 3$ & $4.6 \pm 12$ \\
\hline HFC-23 & $4.3 \pm 2.0^{\mathrm{a})}$ & $8 \pm 2$ & $0.5 \pm 0.03$ & $2 \pm 5$ & $0.8 \pm 0.2$ \\
\hline HFC-227ea & $2.1 \pm 0.83$ & $3 \pm 0.7$ & $1 \pm 0.5$ & $3 \pm 1$ & $1.3 \pm 1$ \\
\hline HFC-236fa & $0.32 \pm 0.12^{\mathrm{a})}$ & $0.6 \pm 0.1$ & $0.1 \pm 0.06$ & $-0.1 \pm 0.5$ & $0.5 \pm 0.2$ \\
\hline HFC-4310mee & $1.5 \pm 0.48$ & $2 \pm 0.4$ & $0.9 \pm 0.3$ & $0.6 \pm 2$ & $0.4 \pm 0.7$ \\
\hline PFC-116 & $1.5 \pm 0.41$ & $2 \pm 0.4$ & $1 \pm 0.1$ & $0.9 \pm 2$ & $0.4 \pm 0.6$ \\
\hline PFC-318 & $1.6 \pm 0.55^{\mathrm{a})}$ & $3 \pm 0.5$ & $0.1 \pm 0.2$ & $0.8 \pm 2$ & $0.02 \pm 0.04$ \\
\hline PFC-14 & $3.7 \pm 1.0^{\mathrm{a})}$ & $7 \pm 1$ & $0.4 \pm 0.2$ & $5 \pm 5$ & $0.6 \pm 0.9$ \\
\hline $\mathrm{SF}_{6}$ & $8.9 \pm 3.0$ & $10 \pm 2$ & $8 \pm 2$ & $6 \pm 2$ & $5.4 \pm 5$ \\
\hline $\mathrm{NF}_{3}$ & $0.32 \pm 0.14^{\mathrm{a})}$ & $0.6 \pm 0.1$ & $0.04 \pm 0.07$ & $0.4 \pm 0.7$ & $0.03 \pm 0.1$ \\
\hline HFO-1234yf & $15 \pm 4.4$ & $14 \pm 3$ & $17 \pm 3$ & $17 \pm 6$ & - \\
\hline HFO-1234ze(E) & $29 \pm 11$ & $42 \pm 8$ & $16 \pm 7$ & $8 \pm 1$ & - \\
\hline HCFO-1233zd(E) & $6.1 \pm 1.1$ & $7 \pm 1$ & $5 \pm 0.5$ & $5 \pm 2$ & - \\
\hline
\end{tabular}

a) Averaged BRM emissions for which the uncertainty ranges do not overlap with the individual estimates.

b) (Reimann et al., 2021)

c) (UNFCCC, 2021) 
- inventory

- JFJ-TRM

- BRM-TRM

- BRM-BI
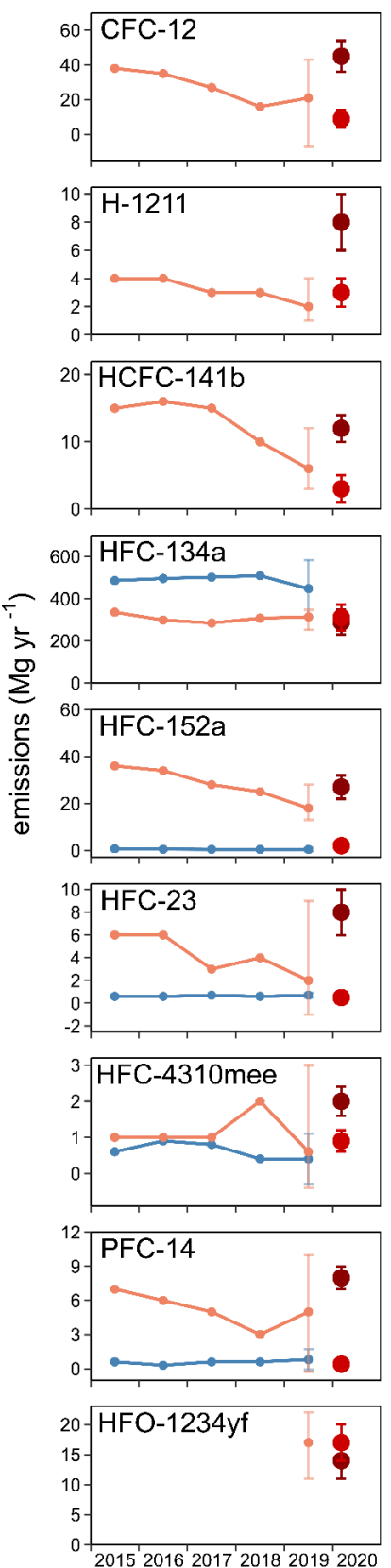
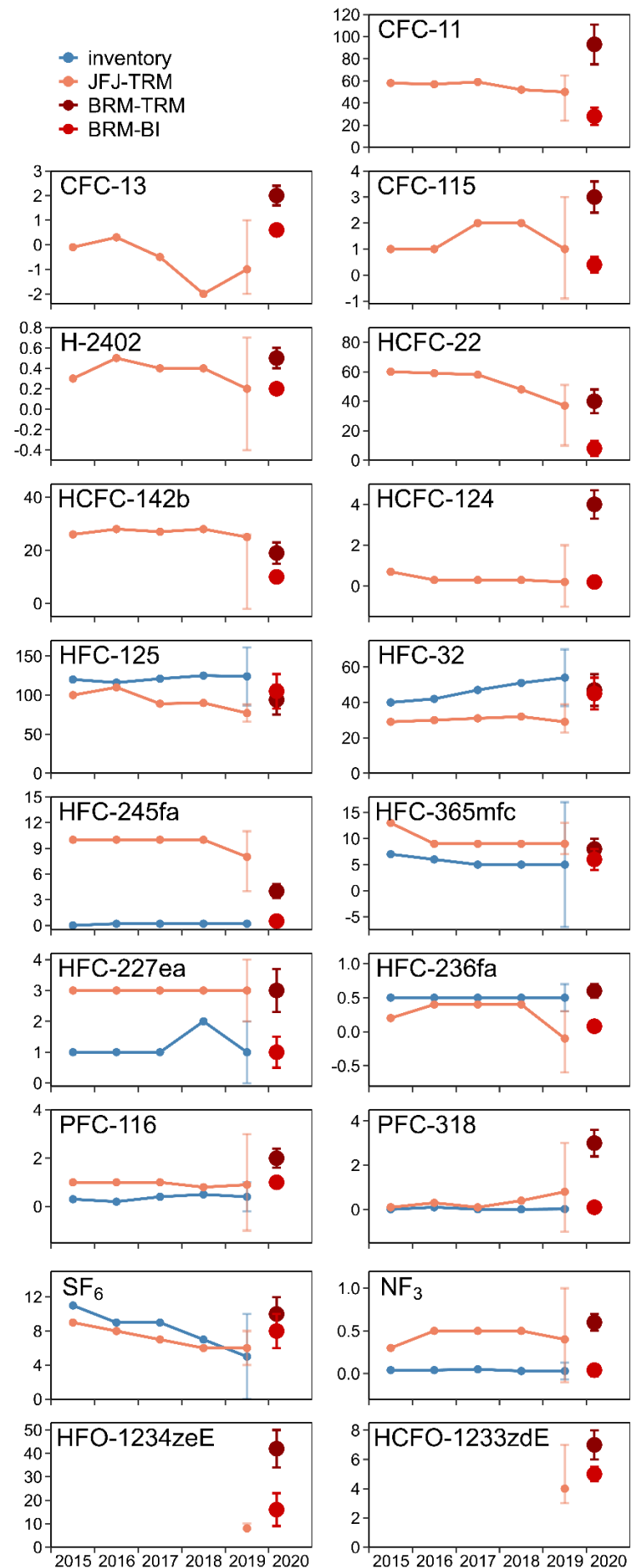

Figure 4: Calculated Swiss emissions for 2019/2020, based on the Beromünster (BRM) measurements, with the tracerratio method (TRM) and Bayesian inverse (BI) modelling. The results are compared to Jungfraujoch (JFJ)-based estimates and the Swiss bottom-up inventory. 

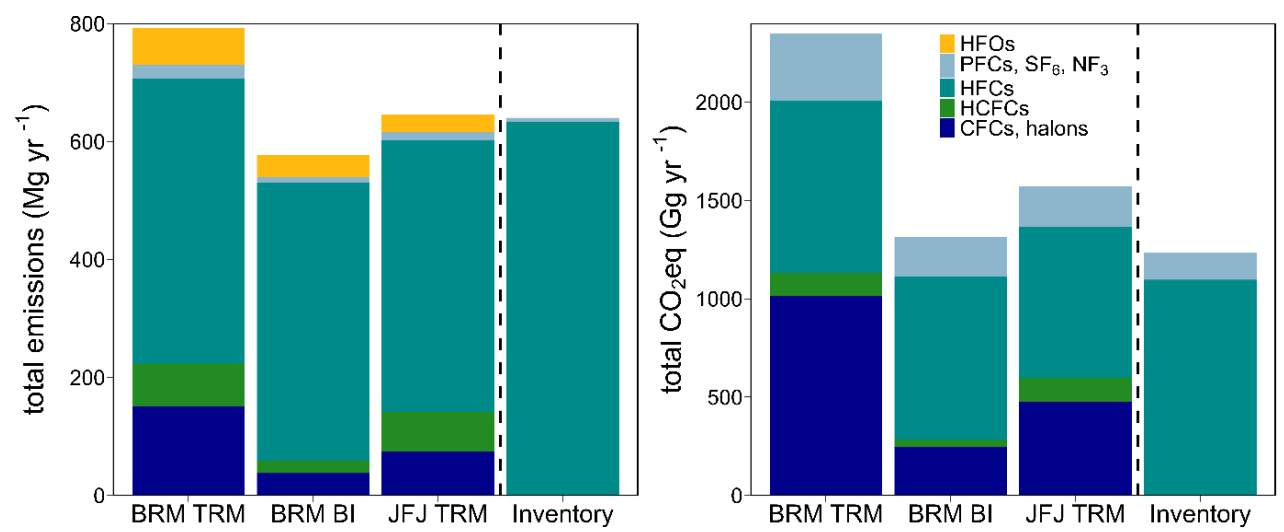

Figure 5: The total Swiss emissions (left) and the corresponding $\mathrm{CO}_{2}$ equivalents (right) for 2019/2020, categorized by substance classes, i.e. chlorofluorocarbons (CFCs) and halons, hydrochlorofluorocarbons (HCFCs), hydrofluorocarbons (HFCs), perfluorocarbons (PFCs), $\mathrm{NF}_{3}, \mathrm{SF}_{6}$, and hydrofluoroolefins (HFOs), for the Beromünster (BRM) and Jungfraujoch (JFJ)-based tracer-ratio method (TRM) results, the Bayesian inversion (BI) results, and the Swiss national inventory. The Swiss inventory only reports emissions for the HFCs, PFCs, $\mathrm{NF}_{3}$, and $\mathrm{SF}_{6}$.

In the following, the estimated emissions are discussed in more detail. Beromünster based emissions are given as the averaged values of the TRM and BI methods. In the text, emissions are given with two significant digits.

\subsubsection{CFCs, halons and HCFCs}

With both methods, the largest emissions of this group were found for CFC-11 and CFC-12, reflecting their substantial use in the past. For both substances, the Beromünster TRM values are higher than the Jungfraujoch values, which in turn are higher than the Beromünster BI results. Over the past years, the CFC-12 emissions observed at Jungfraujoch were decreasing more rapidly than those of CFC-11, which potentially is due to the more stable emissions from CFC-11 from old foams in comparison to CFC-12, which was mostly used in refrigeration.

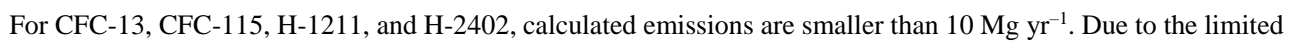
number of pollution events attributed to Switzerland, the results for these four substances are highly uncertain. Furthermore, the TRM emissions for all four substances are invariably higher than the BI and 2019 Jungfraujoch results.

For HCFC-22, HCFC-141b, HCFC-142b, and HCFC-124, the Beromünster TRM values and BI results diverge significantly for all four substances, with systematically higher TRM estimates. For HCFC-141b, for example, the TRM value (11 $\left.\mathrm{Mg} \mathrm{yr}^{-1}\right)$, is more than 3 times higher than the BI value $\left(3 \mathrm{Mg} \mathrm{yr}^{-1}\right)$. Moreover, there is little consistency between our results and those from JFJ, limiting the significance of any conclusions that might be drawn.

\subsubsection{HFCs, $\mathrm{PFCs}, \mathrm{SF}_{6}$, and $\mathrm{NF}_{3}$}

The highest emissions of the investigated HFCs were found for HFC-134a with 300 $\mathrm{Mg} \mathrm{yr}^{-1}$ for both methods.

This value is in good agreement with the Jungfraujoch value of $310 \mathrm{Mg} \mathrm{yr}^{-1}$ (Reimann et al., 2021). The national inventory shows an increasing trend peaking at $510 \mathrm{Mg} \mathrm{yr}^{-1}$ in 2018 and then drops to $450 \mathrm{Mg} \mathrm{yr}^{-1}$ in 2019. Although the 2019 imported amount of HFC-134a corresponds to the yearly import fluctuations, it has been presumed that substitute products are increasingly applied (FOEN, 2021 b). Nevertheless, the latest inventory value is still $33 \%$ higher than the average of the three top-down values. This finding hints at an overestimation of the Swiss HFC-134a bottom-up inventory, which is further supported by other top-down modelling studies for different study domains and time periods. For the UK, Say et al. (2016) and Manning et al. (2021) found significantly lower 
modelled top-down versus inventory estimates for the respective time periods of multiple years between 1995 and 2020. Upon their study results, Say et al. (2016) recommended the re-evaluation of some input-parameters of the UK inventory model. For the European domain, Graziosi et al. (2017) found lower averaged top-down emissions for HFC-134a for the years 2003 - 2014 compared with the sum of the inventories. They suggested an overestimation of emission factors used for the inventory calculations in some countries to be the reason for the high UNFCCC reported values. Lunt et al. (2015) studied emissions on a global scale and reported $21 \%$ lower topdown estimates for all Annex I countries as compared to the aggregated UNFCCC inventories for 2007 to 2012. They emphasized the noticeable divergence found for different countries, presumably due to differently assessed emission factors or activity data.

For HFC-125, the two Beromünster emission estimates are well in accordance with each other and result in an average value of $99 \mathrm{Mg} \mathrm{yr}^{-1}$. This value lies between the Jungfraujoch (77 $\mathrm{Mg} \mathrm{yr}^{-1}$ ) and inventory values $\left(120 \mathrm{Mg} \mathrm{yr}^{-1}\right)$. Again, the measurement-based values are somewhat lower than the inventory value. Also for the UK, Manning et al. (2021) recently reported on average $35 \%$ lower top-down than inventory values for the years 1995 to 2018.

HFC-32 shows the third highest emissions of the investigated HFCs (46 $\left.\mathrm{Mg} \mathrm{yr}^{-1}\right)$. This value exceeds the Jungfraujoch estimate (29 $\mathrm{Mg} \mathrm{yr}^{-1}$ ) and compares slightly better with the 2019 bottom-up inventory $\left(54 \mathrm{Mg} \mathrm{yr}^{-1}\right.$ ), whereas an increasing gap was found between (lower) Jungfraujoch estimates and (higher) inventory estimates during the past years (Reimann et al., 2021), apparently due to a greater rate of growth in the inventory values.

Based on our measurements, the next largest Swiss emissions were attributed to HFC-152a. For this HFC, the TRM, BI, and inventory values differ significantly. A conclusive evaluation of our Beromünster results is not possible. The discrepancy may be due to the fact that for HFC-152a, UNFCCC reported emissions are attributed to the manufacturing, not the emitting countries, which may lead to a distortion of the calculated emissions at the country level. Similar observations of greatly differing top-down and bottom-up estimates have been published before. Manning et al. (2021) found significantly larger inventory than inverse modelling values for the UK. Investigating the global domain, Lunt et al. (2015) reported 8 times higher atmosphere-based emissions of HFC-152a for the Annex I countries for the years 2007 to 2012, but raise the objection of incomplete reporting of this substance for some of the included Annex I countries. Global and (European) regional comparisons between top-down calculated HFC-152a emissions and reported inventory values were also published by Simmonds et al. (2016) who showed varying agreement between the inverse results and reported UNFCCC values for many European countries for the years $2006-2014$.

For HFC-245fa, HFC-365mfc, HFC-23, HFC-227ea, HFC-236fa, HFC-4310mee, and HFC-23, Swiss emissions were determined to be smaller than $10 \mathrm{Mg} \mathrm{yr}^{-1}$. The results compare well to the Jungfraujoch and the inventory values, all showing emissions below $10 \mathrm{Mg} \mathrm{yr}^{-1}$.

Of all investigated substances, PFC-116, PFC-318, PFC-14, $\mathrm{SF}_{6}$, and $\mathrm{NF}_{3}$ are among those with the longest lifetime and the highest 100-year GWP. Their Swiss emissions were all determined below $10 \mathrm{Mg} \mathrm{yr}^{-1}$, which compares well to the Swiss inventory.

\subsubsection{HFOs}

As described in Sect. 3.1, HFOs are increasingly replacing HFCs in various applications (WMO, 2018). Therefore, emissions and atmospheric abundance of these gases are expected to grow in the future (Vollmer et al., 2015). 
Based on the measurements at Beromünster and at Jungfraujoch, we present the first emission estimates for Switzerland. They amount to $15 \mathrm{Mg} \mathrm{yr}^{-1}, 29 \mathrm{Mg} \mathrm{yr}^{-1}$ and $6 \mathrm{Mg} \mathrm{yr}^{-1}$ for HFO-1234yf, HFO-1234ze(E) and HCFO-1233zd(E), respectively. For HFO-1234yf and HCFO-1233zd(E), the 2019 and 2019/2020 Beromünster and Jungfraujoch-based values compare well. For HFO-1234ze(E), the Beromünster-based TRM result (42 $\mathrm{Mg}^{-} \mathrm{yr}^{-}$

$\left.{ }^{1}\right)$ is almost 3 times higher than the BI result $\left(16 \mathrm{Mg} \mathrm{yr}^{-1}\right)$. Both estimates are somewhat higher than the 2019 Jungfraujoch-based value.

\subsection{Swiss source regions}

A significant asset of $\mathrm{BI}$ is its ability to geographically locate a posteriori emission distributions. The corresponding maps for selected halocarbons are shown in Fig.6 (Switzerland) and in Supplement 7 (European domain). The subset of substances includes CFC-11 and HCFC-142b, as representatives for the CFCs and HCFCs, the three most highly emitted HFCs, which are used as refrigerants, the foam blowing agent HFC-365mfc, as well as $\mathrm{SF}_{6}$, and three HFOs.

All a posteriori distributions continue to reflect the population-based distribution, which was used in the a priori emissions. However, there are differences between the compounds, visible as differing pronounced hot spots. CFC-11 and HCFC-142b emissions were especially pronounced for the area around Zurich, which has the highest population density, but were also accentuated for other cities, i.e. Bern, Lucerne, Basel, Lausanne and Geneva. HFC-134a, HFC-125, HFC-32, and HFO-1234yf, all used as cooling agents, were emitted more diffusely across the Swiss Plateau, showing, in addition to the more populated areas, hot spots in other regions (e.g., between Lausanne and Bern). The foam blowing agent HFC-365mfc showed somewhat less pronounced emissions from the populated areas with larger emissions from outside Switzerland dominating the distribution at a wider scale. $\mathrm{SF}_{6}$ showed generally diffuse emissions from the Swiss Plateau, however with some more pronounced grids at Zurich, Basel and Lausanne, a region north of Beromünster, a region west of Bern, and an area west of Lucerne. HFO-1234ze(E) and HCFO-1233zd(E) emissions were especially emphasized in the areas NW to NE of Beromünster, around Basel and Zurich.

In the European frame (Supplement 7), the Swiss emissions of CFC-11 and HCFC-142b were of comparable magnitude as the emissions from the border areas of France and Germany, except for the significantly enhanced area around Zurich. For HFC-134a, HFC-125, HFC-32, SF$_{6}$, and HFO-1234yf, the Swiss emissions were of comparable magnitude as the emissions north of the border in Germany and France, with a diverse distribution of locations with increased emissions. This seems also true for HFO-1234ze(E), for which the area of increased Swiss emissions described above, resembles the emission distribution behind the border to Germany. For HFC-365mfc, compared to Switzerland, enhanced emissions were attributed to France and Germany. For HCFO-1233zd(E), besides the Swiss emissive areas described above, increased emissions were additionally attributed to northern Italy.

The maps of the absolute differences between the a priori and the a posteriori emissions (Supplement 7) show somewhat the same population driven distribution as the relative source maps. However, for all substances except HFO-1234ze(E), the model decreased the a posteriori emissions at the region around Zurich as compared to the a priori distribution. For the HFCs and $\mathrm{SF}_{6}$ the model increased the a posteriori emissions from the southwestern region towards Lausanne. Especially HFC-134a, HFC-25, and HFC-32 show a similar emission distribution, confirming the high correlation of emissions from the populated areas. For HFO-1234ze(E), a posteriori emissions were especially increased around Zurich. 
a

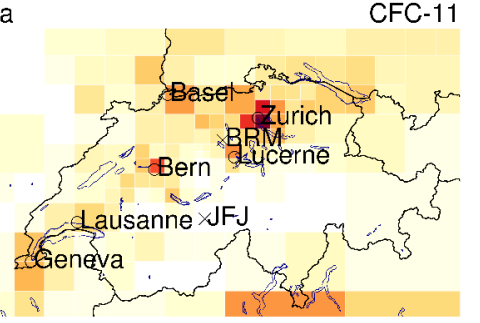

c

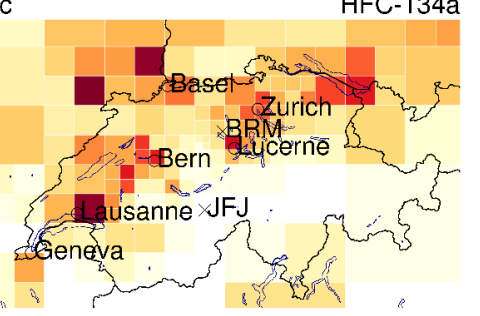

e

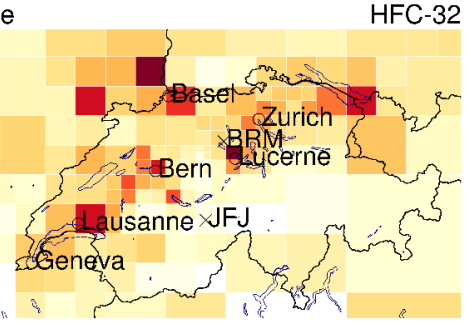

g

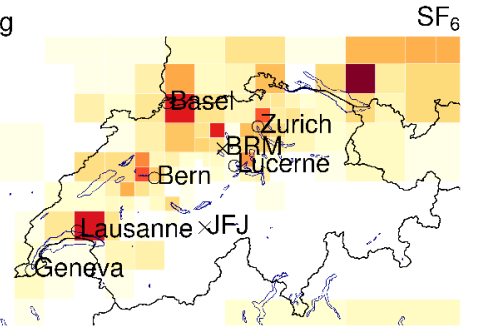

HFO-1234ze(E)

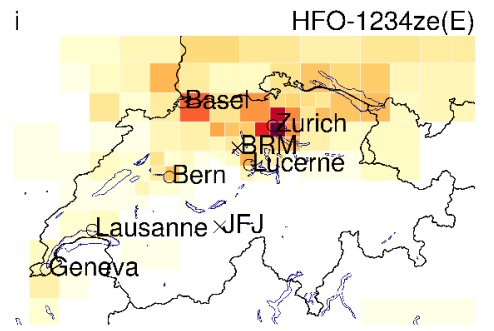

b

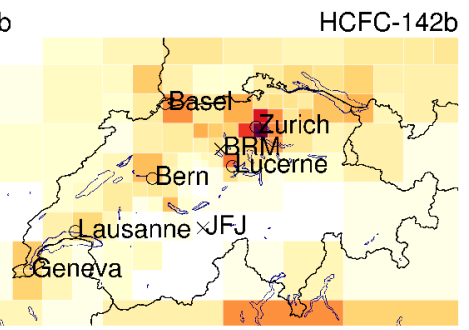

d
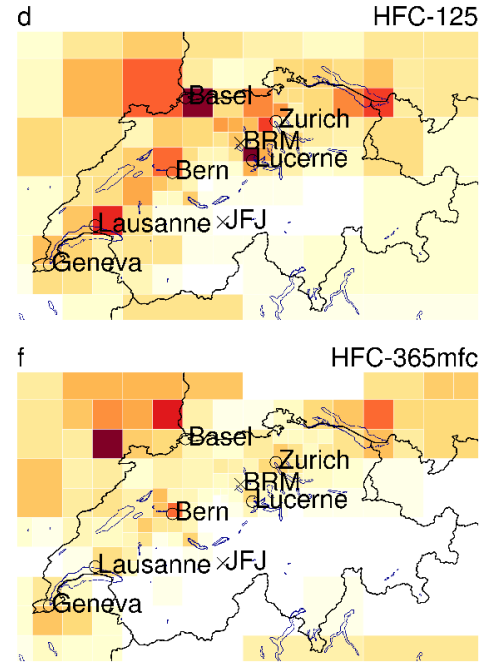

$\mathrm{h}$

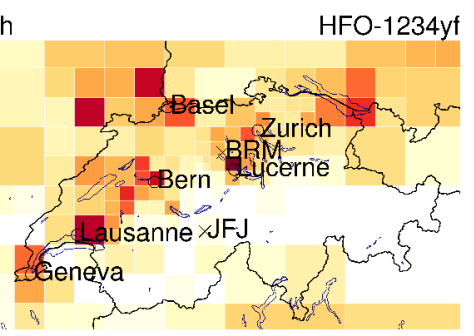

HCFO-1233zd(E)

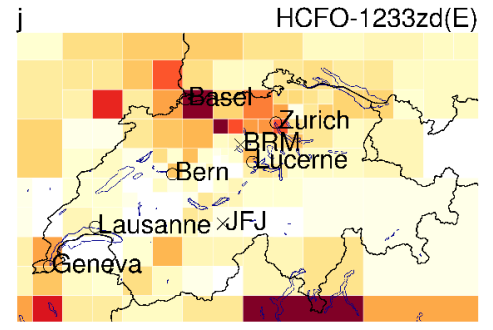

0.2

0.4

0.6

0.8

Figure 6: Emission maps for Switzerland, generated from the Bayesian inverse (BI) modelling. Beromünster (BRM), Jungfraujoch (JFJ), and major Swiss cities are indicated. Gridded emissions (e), given in $\mu \mathrm{g} \mathrm{s}^{-1} \mathrm{~km}^{-2}$, are scaled to the global maximum (emax). 


\section{Conclusions}

In this study, we present the time series measured at Beromünster of four CFCs, two halons, four HCFCs, ten HFCs, three PFCs, $\mathrm{SF}_{6}, \mathrm{NF}_{3}$, and three HFOs. Based on these records, Swiss emissions were determined by two different top-down methods. The results were compared to Jungfraujoch-based estimates, and to the Swiss national inventory, as annually reported to the UNFCCC. For the major CFCs and HCFCs, our emission results are consistent with the ongoing release from remaining banks. For HFC-134a, the Beromünster-based results compare well with the Jungfraujoch estimate, whereas they are approximately one third lower than the inventory value. For HFC-125 and HFC-32, the top-down emission results compare well to the inventory values. For the minor HFCs, the $\mathrm{PFCs}, \mathrm{SF}_{6}$, and $\mathrm{NF}_{3}$, emissions are below $10 \mathrm{Mg} \mathrm{yr}^{-1}$, and, where available, compare well within the order of magnitude to the 2019 UNFCCC reported values. In addition, we present the first emission estimates of the recently introduced unsaturated HFO-1234yf, HFO-1234ze(E), and HCFO-1233zd(E) for Switzerland. Total HFC emissions are in good agreement between the three top-down methods, and in varying agreement for the other substance classes. Moreover, regions with emission sources were defined for a subset of the investigated halocarbons and, for most substances, point at the more densely populated areas of Switzerland. Overall, the measurements at Beromünster provided valuable information for the validation of Swiss regional halocarbon emissions and the allocation of local source areas.

\section{Data availability}

Continuous atmospheric halocarbon measurement data for the AGAGE stations are available from (http://agage.mit.edu/data/agage-data). Measurement data for Tacolneston are available from the Centre of Envi-

logue.ceda.ac.uk/uuid/a18f43456c364789aac726ed365e41d1). Beromünster measurement data are available from the Zenodo data repository (https://doi.org/10.5281/zenodo.5127197, Reiman et al., 2021).

\section{Author contribution}

DR, MKV, SOD, and DS collected and evaluated the measurement data. DR and IK estimated the Swiss halocarbon emissions by the tracer-ratio method and Bayesian inverse modeling, being intensely supported by SH and SR. DR prepared the manuscript with substantial contribution from IK and revision from LE, RZ, and all other coauthors.

\section{Competing interests}

The authors declare that they have no conflict of interest.

\section{Acknowledgements}

We want to thank Matthias Hill, Paul Schlauri and Silvio Harndt from Empa for giving fundamental instrumental and technical support. We acknowledge Rüdiger Schanda from University of Berne for the constructive cooperation at the site. We thank the personnel operating the AGAGE measurement stations, and evaluating and providing 
https://doi.org/10.5194/acp-2021-633

Preprint. Discussion started: 5 August 2021

(C) Author(s) 2021. CC BY 4.0 License.

635 the measurement data from Jungfraujoch, Tacolneston and Mace Head. This research was funded under the project

IHALOME by the Swiss National Science Foundation (SNSF, project 200020_175921). 


\section{References}

Arnold, T., Mühle, J., Salameh, P. K., Harth, C. M., Ivy, D. J., and Weiss, R. F.: Automated Measurement of Nitrogen Trifluoride in Ambient Air, Anal. Chem., 84, 4798-4804, https://doi.org/10.1021/ac300373e, 2012.

Arnold, T., Ivy, D. J., Harth, C. M., Vollmer, M. K., Mühle, J., Salameh, P. K., Paul Steele, L., Krummel, P. B., Wang, R. H. J., Young, D., Lunder, C. R., Hermansen, O., Rhee, T. S., Kim, J., Reimann, S., O’Doherty, S., Fraser, P. J., Simmonds, P. G., Prinn, R. G., and Weiss, R. F.: HFC-43-10mee atmospheric abundances and global emission estimates, Geophys. Res. Lett., 41, 2228-2235, https://doi.org/10.1002/2013GL059143, 2014.

Bergamaschi, P., Danila, A., Weiss, R. F., Ciais, P., Thompson, R. L., Brunner, D., Levin, I., Meijer, Y., Chevallier, F., Janssens-Maenhout, G., Bovensmann, H., Crisp, D., Basu, S., Dlugokencky, E., Engelen, R., Gerbig, C., Günther, D., Hammer, S., Henne, S., Houweling, S., Karstens, U., Kort, E. A., Maione, M., Manning, A. J., Miller, J., Montzka, S., Pandey, S., Peters, W., Peylin, P., Pinty, B., Ramonet, M., Reimann, S., Röckmann, T., Schmidt, M., Strogies, M., Sussams, J., Tarasova, O., Aardenne, J. van, Vermeulen, A. T., and Vogel, F.: Atmospheric monitoring and inverse modelling for verification of greenhouse gas inventories, Publications Office of the European Union, Luxembourg, Science for Policy Rep. EUR 29276 EN, 109 pp., 2018.

Berhanu, T. A., Satar, E., Schanda, R., Nyfeler, P., Moret, H., Brunner, D., Oney, B., and Leuenberger, M.: Measurements of greenhouse gases at Beromünster tall-tower station in Switzerland, Atmos. Meas. Tech., 9, 2603-2614, https://doi.org/10.5194/amt-9-2603-2016, 2016.

Brunner, D., Arnold, T., Henne, S., Manning, A., Thompson, R. L., Maione, M., O’Doherty, S., and Reimann, S.: Comparison of four inverse modelling systems applied to the estimation of HFC-125, HFC-134a, and $\mathrm{SF}_{6}$ emissions over Europe, Atmos. Chem. Phys., 17, 10651-10674, https://doi.org/10.5194/acp-17-10651-2017, 2017.

EU: Regulation (EU) No 517/2014 of the European Parliament and of the Council of 16 April 2014 on fluorinated greenhouse gases and repealing Regulation (EC) No 842/2006, Official Journal of the European Union, Policy Document, 36 pp., 2014.

FOEN: Switzerland's Greenhouse Gas Inventory 1990-2019: National Inventroy Report, Federal Office for the Environment FOEN, Climate Division, 3003 Bern, Switzerland, Rep., 643 pp., 2021 a.

FOEN: Swiss Federal Office for the Environment, Department of the Environment, Transport, Energy and Communications (DETEC), Henry Wöhrnschimmel, May 2021 b.

Graziosi, F., Arduini, J., Furlani, F., Giostra, U., Christofanelli, P., Fang, X., Hermanssen, O., Lunder, C., Maenhout, G., O’Doherty, S., Reimann, S., Schmidbauer, N., Vollmer, M. K., Young, D., and Maione, M.: European emissions of the powerful greenhouse gases hydrofluorocarbons inferred from atmospheric measurements and their comparison with annual national reports to UNFCCC, Atmos. Environ., 158, 8597, https://doi.org/10.1016/j.atmosenv.2017.03.029, 2017.

Guevara, M., Jorba, O., Tena, C., Denier van der Gon, H., Kuenen, J., Elguindi, N., Darras, S., Granier, C., and Pérez García-Pando, C.: Copernicus Atmosphere Monitoring Service TEMPOral profiles (CAMS-TEMPO): Global and European emission temporal profile maps for atmospheric chemistry modelling, Earth Syst. Sci. Data, 13, 367-404, https://doi.org/10.5194/essd-13-367-2021, 2021.

Henne, S., Brunner, D., Oney, B., Leuenberger, M., Eugster, W., Bamberger, I., Meinhardt, F., Steinbacher, M., and Emmenegger, L.: Validation of the Swiss methane emission inventory by atmospheric observations and inverse modelling, Atmos. Chem. Phys., 16, 3683-3710, https://doi.org/10.5194/acp-16-3683-2016, 2016.

Keller, C. A., Hill, M., Vollmer, M. K., Henne, S., Brunner, D., Reimann, S., O’Doherty, S., Arduini, J., Maione, M., Ferenczi, Z., Haszpra, L., Manning, A. J., and Peter, T.: European Emissions of Halogenated Greenhouse Gases Inferred from Atmospheric Measurements, Environ. Sci. Technol., 46, 217-225, https://doi.org/10.1021/es202453j, 2012.

Laube, J. C., Martinerie, P., Witrant, E., Blunier, T., Schwander, J., Brenninkmeijer, C. A. M., Schuck, T. J., Bolder, M., Röckmann, T., van der Veen, C., Bönisch, H., Engel, A., Mills, G. P., Newland, M. J., Oram, D. E., Reeves, C. E., and Sturges, W. T.: Accelerating growth of HFC-227ea $(1,1,1,2,3,3,3-$ heptafluoropropane) in the atmosphere, Atmos. Chem. Phys., 10, 5903-5910, https://doi.org/10.5194/acp10-5903-2010, 2010.

Le Bris, K., DeZeeuw, J., Godin, P. J., and Strong, K.: Infrared absorption cross-sections, radiative efficiency and global warming potential of HFC-43-10mee, J. Mol. Spectrosc., 348, 64-67, https://doi.org/10.1016/j.jms.2017.06.004, 2018

Lefrancois, F., Jesswein, M., Thoma, M., Engel, A., Stanley, K., and Schuck, T.: Non-target analysis using gas chromatography with time-of-flight mass spectrometry: application to time series of fourth generation synthetic halocarbons at Taunus Observatory (Germany), Atmos. Meas. Tech. Discuss., 1-25, 
https://doi.org/10.5194/amt-2020-488, 2021.

Li, P., Mühle, J., Montzka, S. A., Oram, D. E., Miller, B. R., Weiss, R. F., Fraser, P. J., and Tanhua, T.: Atmospheric histories, growth rates and solubilities in seawater and other natural waters of the potential transient tracers HCFC-22, HCFC-141b, HCFC-142b, HFC-134a, HFC-125, HFC-23, PFC-14 and PFC116, Ocean Sci., 15, 33-60, https://doi.org/10.5194/os-15-33-2019, 2019.

Lunt, M. F., Rigby, M., Ganesan, A. L., Manning, A. J., Prinn, R. G., O’Doherty, S., Mühle, J., Harth, C. M., Salameh, P. K., Arnold, T., Weiss, R. F., Saito, T., Yokouchi, Y., Krummel, P. B., Steele, L. P., Fraser, P. J., Li, S., Park, S., Reimann, S., Vollmer, M. K., Lunder, C., Hermansen, O., Schmidbauer, N., Maione, M., Arduini, J., Young, D., and Simmonds, P. G.: Reconciling reported and unreported HFC emissions with atmospheric observations, P. Natl. Acad. Sci. USA, 112, 5927-5931, https://doi.org/10.1073/pnas.1420247112, 2015.

Manning, A. J., Redington, A. L., Say, D., Doherty, S. O., Young, D., Simmonds, P. G., Vollmer, M. K., Mühle, J., Arduini, J., Spain, G., Wisher, A., Maione, M., Schuck, T. J., Stanley, K., Reimann, S., Engel, A., Krummel, B., Fraser, P. J., Harth, C. M., Salameh, P. K., Weiss, R. F., Gluckman, R., Brown, P. N., Watterson, J. D., and Arnold, T.: Evidence of a recent decline in UK emissions of HFCs determined by the InTEM inverse model and atmospheric measurements, Atmos. Chem. Phys. Discuss. [preprint], https://doi.org/10.5194/acp-2021-261, 13 April 2021.

Miller, B. R., Weiss, R. F., Salameh, P. K., Tanhua, T., Greally, B. R., Mühle, J., and Simmonds, P. G.: Medusa: A Sample Preconcentration and GC/MS Detector System for in Situ Measurements of Atmospheric Trace Halocarbons, Hydrocarbons, and Sulfur Compounds, Anal. Chem., 80, 1536-1545, https://doi.org/10.1021/ac702084k, 2008.

Miller, B. R., Rigby, M., Kuijpers, L. J. M., Krummel, P. B., Steele, L. P., Leist, M., Fraser, P. J., McCulloch, A., Harth, C., Salameh, P., Mühle, J., Weiss, R. F., Prinn, R. G., Wang, R. H. J., O’Doherty, S., Greally, B. R., and Simmonds, P. G.: HFC-23 $\left(\mathrm{CHF}_{3}\right)$ emission trend response to $\mathrm{HCFC}-22\left(\mathrm{CHClF}_{2}\right)$ production and recent HFC-23 emission abatement measures, Atmos. Chem. Phys., 10, 7875-7890, https://doi.org/10.5194/acp10-7875-2010, 2010.

Miller, J. B., Lehman, S. J., Montzka, S. A., Sweeney, C., Miller, B. R., Karion, A., Wolak, C., Dlugokencky, E. J., Southon, J., Turnbull, J. C., and Tans, P. P.: Linking emissions of fossil fuel CO2 and other anthropogenic trace gases using atmospheric 14CO2, J. Geophys. Res., 117, 1-23, https://doi.org/10.1029/2011JD017048, 2012.

Montzka, S. A., Kuijpers, L., Battle, M. O., Aydin, M., Verhulst, K. R., Saltzman, E. S., and Fahey, D. W.: Recent increases in global HFC-23 emissions, Geophys. Res. Lett., 37, 1-5, https://doi.org/10.1029/2009GL041195, 2010.

Montzka, S. A., Dutton, G. S., Portmann, R. W., Chipperfield, M. P., Davis, S., Feng, W., Manning, A. J., Ray, E., Rigby, M., Hall, B. D., Siso, C., David Nance, J., Krummel, P. B., Mühle, J., Young, D., O’Doherty, S., Salameh, P. K., Harth, C. M., Prinn, R. G., Weiss, R. F., Elkins, J. W., Walter-Terrinoni, H., and Theodoridi, C.: A decline in global CFC-11 emissions during 2018-2019, Nature, 590, 428-432, https://doi.org/10.1038/s41586-021-03260-5, 2021.

NOAA: https://www.esrl.noaa.gov/gmd/hats/, last access: 28 May 2021.

Oney, B., Henne, S., Gruber, N., Leuenberger, M., Bamberger, I., Eugster, W., and Brunner, D.: The CarboCount CH sites: characterization of a dense greenhouse gas observation network, Atmos. Chem. Phys., 15, 11147 11164, https://doi.org/10.5194/acp-15-11147-2015, 2015.

Oney, B., Gruber, N., Henne, S., Leuenberger, M., and Brunner, D.: A CO-based method to determine the regional biospheric signal in atmospheric $\mathrm{CO}_{2}$, Tellus B, 69, 1-25, https://doi.org/10.1080/16000889.2017.1353388, 2017.

Oram, D. E., Sturges, W. T., Penkett, S. A., McCulloch, A., and Fraser, P. J.: Growth of fluoroform (CHF 3 , HFC23) in the background atmosphere, Geophys. Res. Lett., 25, 35-38, https://doi.org/10.1029/97GL03483, 1998.

Pisso, I., Sollum, E., Grythe, H., Kristiansen, N. I., Cassiani, M., Eckhardt, S., Arnold, D., Morton, D., Thompson, R. L., Groot Zwaaftink, C. D., Evangeliou, N., Sodemann, H., Haimberger, L., Henne, S., Brunner, D., Burkhart, J. F., Fouilloux, A., Brioude, J., Philipp, A., Seibert, P., and Stohl, A.: The Lagrangian particle dispersion model FLEXPART version 10.4, Geosci. Model Dev., 12, 4955-4997, https://doi.org/10.5194/gmd-12-4955-2019, 2019.

Prinn, R. G., Weiss, R. F., Fraser, P. J., Simmonds, P. G., Cunnold, D. M., Alyea, F. N., O’Doherty, S., Salameh, P., Miller, B. R., Huang, J., Wang, R. H. J., Hartley, D. E., Harth, C., Steele, L. P., Sturrock, G., Midgley, P. M., and McCulloch, A.: A history of chemically and radiatively important gases in air deduced from ALE/GAGE/AGAGE, J. Geophys. Res., 105, 17751-17792, https://doi.org/10.1029/2000JD900141, 2000.

Prinn, R. G., Weiss, R. F., Arduini, J., Arnold, T., Langley DeWitt, H., Fraser, P. J., Ganesan, A. L., Gasore, J., Harth, C. M., Hermansen, O., Kim, J., Krummel, P. B., Li, S., Loh, Z. M., Lunder, C. R., Maione, M., Manning, A. J., Miller, B. R., Mitrevski, B., Mühle, J., O’Doherty, S., Park, S., Reimann, S., Rigby, M., Saito, T., Salameh, P. K., Schmidt, R., Simmonds, P. G., Paul Steele, L., Vollmer, M. K., Wang, R. H., Yao, 
B., Yokouchi, Y., Young, D., and Zhou, L.: History of chemically and radiatively important atmospheric gases from the Advanced Global Atmospheric Gases Experiment (AGAGE), Earth Syst. Sci. Data, 10, 985 1018, https://doi.org/10.5194/essd-10-985-2018, 2018.

Reimann, S., Schaub, D., Stemmler, K., Folini, D., Hill, M., Hofer, P., Buchmann, B., Simmonds, P. G., Greally, B. R., and O'Doherty, S.: Halogenated greenhouse gases at the Swiss High Alpine Site of Jungfraujoch (3580 m asl): Continuous measurements and their use for regional European source allocation, J. Geophys. Res., 109, 1-12, https://doi.org/10.1029/2003JD003923, 2004.

Reimann, S., Vollmer, M. K., Henne, S., Brunner, D., Steinbacher, M., Schlauri, P., Hill, M., and Emmenegger, L.: CLIMGAS-CH Kontinuierliche Messung der Nicht- $\mathrm{CO}_{2}$-Treibhausgase auf dem Jungfraujoch und in Beromünster, Laboratory for Air Pollution/ Environmental Technology, Empa, Swiss Federal Laboratories for Materials Science and Technologies, Dübendorf, Switzerland, 94 pp., 2021.

Reiman, S., Rust, D., and Vollmer, M. K.: Atmospheric Halocarbon Observations at Beromünster, Switzerland, available at: https://doi.org/10.5281/zenodo.5127197, last access: 23 July 2021.

Ruckstuhl, A. F., Henne, S., Reimann, S., Steinbacher, M., Vollmer, M. K., O’Doherty, S., Buchmann, B., and Hueglin, C.: Robust extraction of baseline signal of atmospheric trace species using local regression, Atmos. Meas. Tech., 5, 2613-2624, https://doi.org/10.5194/amt-5-2613-2012, 2012.

Satar, E., Berhanu, T. A., Brunner, D., Henne, S., and Leuenberger, M.: Continuous $\mathrm{CO}_{2} / \mathrm{CH}_{4} / \mathrm{CO}$ measurements (2012-2014) at Beromunster tall tower station in Switzerland, Biogeosciences, 13, 2623-2635, https://doi.org/10.5194/bg-13-2623-2016, 2016.

Say, D., Manning, A. J., O’Doherty, S., Rigby, M., Young, D., and Grant, A.: Re-Evaluation of the UK's HFC134a Emissions Inventory Based on Atmospheric Observations, Environ. Sci. Technol., 50, 11129-11136, https://doi.org/10.1021/acs.est.6b03630, 2016.

Schoenenberger, F., Henne, S., Hill, M., Vollmer, M. K., Kouvarakis, G., Mihalopoulos, N., O’Doherty, S., Maione, M., Emmenegger, L., Peter, T., and Reimann, S.: Abundance and sources of atmospheric halocarbons in the Eastern Mediterranean, Atmos. Chem. Phys., 18, 4069-4092, https://doi.org/10.5194/acp18-4069-2018, 2018.

Schuck, T. J., Lefrancois, F., Gallmann, F., Wang, D., Jesswein, M., Hoker, J., Bönisch, H., and Engel, A.: Establishing long-term measurements of halocarbons at Taunus Observatory, Atmos. Chem. Phys., 18, 16553-16569, https://doi.org/10.5194/acp-18-16553-2018, 2018.

Seibert, P. and Frank, A.: Source-receptor matrix calculation with a Lagrangian particle dispersion model in backward mode, Atmos. Chem. Phys., 4, 51-63, https://doi.org/10.5194/acp-4-51-2004, 2004.

Simmonds, P. G., Rigby, M., Manning, A. J., Lunt, M. F., O’Doherty, S., McCulloch, A., Fraser, P. J., Henne, S., Vollmer, M. K., Mühle, J., Weiss, R. F., Salameh, P. K., Young, D., Reimann, S., Wenger, A., Arnold, T., Harth, C. M., Krummel, P. B., Steele, L. P., Dunse, B. L., Miller, B. R., Lunder, C. R., Hermansen, O., Schmidbauer, N., Saito, T., Yokouchi, Y., Park, S., Li, S., Yao, B., Zhou, L. X., Arduini, J., Maione, M., Wang, R. H. J., Ivy, D., and Prinn, R. G.: Global and regional emissions estimates of 1,1-difluoroethane (HFC-152a, $\mathrm{CH}_{3} \mathrm{CHF}_{2}$ ) from in situ and air archive observations, Atmos. Chem. Phys., 16, 365-382, https://doi.org/10.5194/acp-16-365-2016, 2016.

Simmonds, P. G., Rigby, M., McCulloch, A., O’Doherty, S., Young, D., Mühle, J., Krummel, P. B., Steele, P., Fraser, P. J., Manning, A. J., Weiss, R. F., Salameh, P. K., Harth, C. M., Wang, R. H. J., and Prinn, R. G.: Changing trends and emissions of hydrochlorofluorocarbons (HCFCs) and their hydrofluorocarbon (HFCs) replacements, Atmos. Chem. Phys., 17, 4641-4655, https://doi.org/10.5194/acp-17-4641-2017, 2017.

Stanley, K. M., Say, D., Mühle, J., Harth, C. M., Krummel, P. B., Young, D., O’Doherty, S. J., Salameh, P. K., Simmonds, P. G., Weiss, R. F., Prinn, R. G., Fraser, P. J., and Rigby, M.: Increase in global emissions of HFC-23 despite near-total expected reductions, Nat. Commun., 11, 1-6, https://doi.org/10.1038/s41467019-13899-4, 2020.

Stemmler, K., Folini, D., Ubl, S., Vollmer, M. K., Reimann, S., O’Doherty, S., Greally, B. R., Simmonds, P. G., and Manning, A. J.: European Emissions of HFC-365mfc, a Chlorine-Free Substitute for the Foam Blowing Agents HCFC-141b and CFC-11, Environ. Sci. Technol., 41, 1145-1151, https://doi.org/10.1021/es061298h, 2007.

Stohl, A., Forster, C., Frank, A., Seibert, P., and Wotawa, G.: Technical note: The Lagrangian particle dispersion model FLEXPART version 6.2, Atmos. Chem. Phys., 5, 2461-2474, https://doi.org/10.5194/acp-5-2461$2005,2005$.

UNEP: UNEP: Handbook for the Montreal Protocol on Substances that Deplete the Ozone Layer, 14th edition, Ozone Secretariat, Nairobi, Kenya, 937 pp., ISBN: 978-9966-076-79-3, 2020.

UNFCCC: https://unfccc.int/ghg-inventories-annex-i-parties/2021: last access 11.5.2021.

Vollmer, M. K., Reimann, S., Folini, D., Porter, L. W., and Steele, L. P.: First appearance and rapid growth of anthropogenic HFC-245fa $\left(\mathrm{CHF}_{2} \mathrm{CH}_{2} \mathrm{CF}_{3}\right)$ in the atmosphere, Geophys. Res. Lett., 33, 1-5, https://doi.org/10.1029/2006GL026763, 2006.

Vollmer, M. K., Miller, B. R., Rigby, M., Reimann, S., Mühle, J., Krummel, P. B., O’Doherty, S., Kim, J., Rhee, T. S., Weiss, R. F., Fraser, P. J., Simmonds, P. G., Salameh, P. K., Harth, C. M., Wang, R. H. J., Steele, L. 
P., Young, D., Lunder, C. R., Hermansen, O., Ivy, D., Arnold, T., Schmidbauer, N., Kim, K. R., Greally, B. R., Hill, M., Leist, M., Wenger, A., and Prinn, R. G.: Atmospheric histories and global emissions of the anthropogenic hydrofluorocarbons HFC-365mfc, HFC-245fa, HFC-227ea, and HFC-236fa, J. Geophys. Res., 116, 1-16, https://doi.org/10.1029/2010JD015309, 2011.

Vollmer, M. K., Reimann, S., Hill, M., and Brunner, D.: First Observations of the Fourth Generation Synthetic Halocarbons HFC-1234yf, HFC-1234ze(E), and HCFC-1233zd(E) in the Atmosphere, Environ. Sci. Technol., 49, 2703-2708, https://doi.org/10.1021/es505123x, 2015.

Vollmer, M. K., Young, D., Trudinger, C. M., Mühle, J., Henne, S., Rigby, M., Park, S., Li, S., Guillevic, M., Mitrevski, B., Harth, C. M., Miller, B. R., Reimann, S., Yao, B., Steele, L. P., Wyss, S. A., Lunder, C. R., Arduini, J., McCulloch, A., Wu, S., Rhee, T. S., Wang, R. H. J., Salameh, P. K., Hermansen, O., Hill, M., Langenfelds, R. L., Ivy, D., O’Doherty, S., Krummel, P. B., Maione, M., Etheridge, D. M., Zhou, L., Fraser, P. J., Prinn, R. G., Weiss, R. F., and Simmonds, P. G.: Atmospheric histories and emissions of chlorofluorocarbons CFC-13 (CClF3), ¿CFC-114 (C2Cl2F4), and CFC-115 (C2ClF5), Atmos. Chem. Phys., 979-1002, https://doi.org/10.5194/acp-18-979-2018, 2018.

Weiss, R. F. and Prinn, R. G.: Quantifying greenhouse-gas emissions from atmospheric measurements: a critical reality check for climate legislation, Philos. T. R. Soc. A, 369, 1925-1942, https://doi.org/10.1098/rsta.2011.0006, 2011.

WMO: Scientific Assessment of Ozone Depletion: 2010, Global Ozone Research and Monitoring Project-Report No. 52, Geneva, Switzerland, 442 pp., 2010.

WMO: Scientific Assessment of Ozone Depletion: 2018, Global Ozone Research and Monitoring Project-Report No. 58, Geneva, Switzerland, 588 pp., 2018.

Yao, B., Vollmer, M. K., Zhou, L. X., Henne, S., Reimann, S., Li, P. C., Wenger, A., and Hill, M.: In-situ measurements of atmospheric hydrofluorocarbons (HFCs) and perfluorocarbons (PFCs) at the Shangdianzi regional background station, China, Atmos. Chem. Phys., 12, 10181-10193, https://doi.org/10.5194/acp-1210181-2012, 2012. 